\title{
TALFĪQ SEBAGAI SALAH SATU METOD PENYELESAIAN HUKUM DI INSTITUSI-INSTITUSI KEWANGAN ISLAM DI MALAYSIA: SUATU ULASAN LITERATUR*
}

\author{
Talfiq As A Legal Solutions in Islamic Financial \\ Institutions in Malaysia: A Literature Review
}

\author{
Mohd Hafiz Jamaludin ${ }^{1}$ \\ Ahmad Hidayat Buang ${ }^{2}$
}

\begin{abstract}
Talfiq is widely used by the present Islamic scholars in formulating current laws, especially in the field of Islamic finance. In this article, the researcher has reviewed a number of published articles with the purpose to analyze several matters which possess direct relationship with the concept of talfiq and its application in the field of Islamic finance. The researcher had deliberately elaborate the concept of talfiq and the debates by scholars, as well as the applications on this concept. Besides that, the
\end{abstract}

* Penulis merakamkan penghargaan kepada Program Penyelidikan Kewangan Islam MOHE-UM-INCEIF No Geran MO007-2017 di atas pemberian dana penyelidikan bagi menyiapkan penulisan artikel ini.

1 Senior Lecturer, Department of Shariah and Law, Academy of Islamic Studies, University of Malaya, 50603 Kuala Lumpur, Malaysia, hafiz_usul@um.edu.my

2 Professor, Department of Shariah and Law, Academy of Islamic Studies, University of Malaya, 50603 Kuala Lumpur, Malaysia, ahidayat@um.edu.my 
researcher also explained the concept of Shariah supervision, the Shariah Advisory Council (SAC) of Bank Negara Malaysia and the legal solutions methods employed by the Shariah supervision body of Islamic financial institutions from the studies done by the previous researchers. This study reveals that the studies on talfiq including the ruling of its usage as a legal solution method need to continue in order to complete the understanding on this concept. Furthermore, specific studies on legal solution method in Islamic financial institutions need to be carried out so as to produce a specific legal solution method to be used as a guide to the Shariah supervision body of Islamic financial institutions currently.

Keywords: talfiq, school of thought, principles of Islamic Jurisprudence, Islamic finance, Central Bank of Malaysia, Shariah Advisory Council (SAC) of Bank Negara Malaysia

\section{PENDAHULUAN}

Talfíq merupakan salah satu konsep yang diperbincangkan dalam disiplin ilmu usul fiqh ketika perbahasan berkenaan konsep ijtihad dan juga taqlid. Secara lebih khusus, ia dibincangkan dalam syarat-syarat taqlid kerana para ulama usul fiqh terdahulu kebanyakannya berpandangan bahawa taqlid dalam permasalahan furu' dibenarkan dengan syarat tidak membawa kepada talfíq. Walau bagaimanapun, perbahasan terperinci bagi konsep talfiq masih sukar diperoleh dalam kitab-kitab usul fiqh kerana ia merupakan satu tajuk kecil daripada perbahasan-perbahasan lain yang menjadi topik utama yang diperbincangkan dalam ilmu usul fiqh. Setelah bermulanya zaman tajdid, para ulama mula membincangkan berkenaan konsep ijtihad dengan tujuan untuk menghidupkan semula pengamalan ijtihad dan membebaskan masyarakat daripada sikap taksub kepada sesebuah mazhab. Ini telah menyebabkan penulisan-penulisan berkenaan konsep ijtihad, taqlid dan juga talfiq semakin banyak dan konsep-konsep ini mula diperbahaskan oleh para ulama secara lebih terperinci. Penggunaan konsep talfí juga semakin banyak dilakukan khususnya dalam bidang muamalat bagi memberikannya penyelesaian-penyelesaian yang lebih pantas terhadap segala permasalahan yang timbul dalam permasalahan muamalat moden dewasa ini. Justeru, kajian ini merupakan kajian literatur bagi menganalisis penulisan-penulisan dan kajian-kajian berkenaan konsep talfiq . Kajian ini juga melihat kepada penulisan-penulisan berkenaan badanbadan pengawasan Syariah yang ditubuhkan bagi mengawal selia perjalanan institusi-institusi kewangan Islam. Ini kerana, penyelidik ingin membuat kajian lanjutan tentang bagaimana konsep talfiq telah diaplikasikan dalam resolusi- 
resolusi Syariah yang dikeluarkan oleh Majlis Penasihat Syariah Bank Negara Malaysia (MPS BNM).

\section{TAKRIF TALFĪQ}

Perbahasan berkenaan konsep talfiq telah merangkumi pelbagai aspek seperti takrif, sejarah, pembahagian dan aspek paling penting berkenaan hukum penggunaan konsep talfiq itu sendiri. Dari aspek takrif, pelbagai takrif telah dikemukakan oleh para pengkaji dalam menjelaskan maksud sebenar bagi konsep talfiq. Birgit Krawietz menyatakan ketiadaan satu takrif yang standard bagi talfiq ini adalah disebabkan kebanyakan penulis muslim mempunyai gambaran yang berbeza setiap kali membincangkan permasalahan talfiq . ${ }^{3}$ Takrif yang agak masyhur yang sering digunakan oleh para pengkaji ialah takrif yang dikemukakan oleh Muhammad Sa'id al-Bani (m.1933M) iaitu menghasilkan satu bentuk penyelesaian hukum yang tidak diakui oleh mana-mana mujtahid. Al-Bani seterusnya menghuraikan takrif yang diberikan tersebut dengan menyatakan bahawa talfiq boleh berlaku apabila seseorang mencampur adukkan satu permasalahan di antara dua pendapat atau lebih sehingga menghasilkan satu gabungan penyelesaian hukum yang tidak diperakui dan dianggap sebagai tidak sah dan terbatal oleh mana-mana mujtahid. ${ }^{4}$ Gabungan pendapat daripada beberapa mazhab atau beberapa ulama dalam satu urusan juga menyebabkan lahirnya satu bentuk hukum baru dan dianggap sebagai satu hukum yang tidak sah dan terbatal. ${ }^{5}$ Takrif seperti ini turut dikemukakan oleh beberapa pengkaji terkini seperti Āyah 'Abd al-Salām, ${ }^{6}$ Sulayman Yūsuf

3 Krawietz, B., 'Cut and Paste in Legal Rules: Designing Islamic Norms with Talfíq,' Die Welt Des Islams, vol. 42/1 (2002): 7.

4 Al-Banī, M. S., 'Umdah al-Taḥqìq fì al-Taqlid wa al-Talfíq (Dimashq: Dār alQadirī, 1997), 91.

$5 \quad$ Sa'ad al-'Anzī, 'al-Talfīq fì al-Fatawā,' Majallah al-Sharī'ah wa al-Dirāsah al-Islämiyyah, vol. 38 (1999), 275; Ruzman Md. Noor, 'Kedudukan Bayyinah, Syahādah dan Qarīnah dalam Penggubalan Undang-Undang Islam di Malaysia,' Jurnal Syariah, vol. 16/2 (2008): 348.

6 Āyah 'Abd al-Salām, 'al-Talfīq wa Tatabbu' al-Rukhaș wa Tațbīqātuhu fī al'Ibādat wa al-Aḥwāl al-Shakhsiyyah,' (Disertasi Sarjana, Jami'ah al-Khalīl, Hebron, Palestin, 2006), 60 \& 61. 
al-Syaihan, ${ }^{7}$ Muhammad Ahmad Mustarihi, ${ }^{8}$ Bilal Mahmud al-Khaylah, ${ }^{9}$ Yasin Karamatullah Makhdum, ${ }^{10}$ dan Maszlee Malik. ${ }^{11}$

Talfiq juga telah ditakrifkan oleh sebahagian pengkaji sebagai peminjaman pendapat secara bebas daripada pelbagai mazhab tanpa terikat dengan sesuatu mazhab. ${ }^{12}$ Takrif ini dilihat agak longgar dengan menyatakan pengambilan pendapat mazhab secara bebas semata-mata akan menyebabkan berlakunya amalan talfiq. Haim Gerber turut mengemukakan takrif yang agak longgar dengan menyatakan bahawa talfiq merupakan peminjaman terhadap penyelesaian hukum yang diberikan oleh mazhab yang lain. ${ }^{13}$ Manakala, Butti Sultan al-Muhairi pula mentakrifkan talfiq sebagai gabungan sebahagian daripada pandangan mazhab dengan sebahagian pandangan mazhab yang lain. ${ }^{14}$ Ibrahim pula mentakrifkan talfiq sebagai amalan memilih pendapatpendapat mazhab yang berbeza secara sewenang-wenangnya. ${ }^{15}$

Seterusnya, talfiq ditakrifkan oleh sebahagian pengkaji sebagai proses perbandingan beberapa hukum mazhab dan pemilihan pendapat yang paling sesuai bagi tujuan untuk memberi kemaslahatan kepada masyarakat dan

7 Sulayman Yūsuf al-Shayhan, 'al-Fatwā fĩ al-Urdun Tarīkhan wa Fiqhan wa Manhajan,' (Ph.D Thesis, University of Jordan, 2008), 48.

8 Muhammad Aḥmad Mustarihi, 'Ta'amul al-Jam'iyyat al-Ta'awūniyyah alIstithmāriyyah ma'a al-'Umala al-Dirāsah Fiqhiyyah Muqāranah,' (Ph.D Thesis, The World Islamic Sciences and Education University, Jordan, 2012), 64.

9 Al-Khalaylah, B. M., 'Mada Tațbīq al-Mu'assasah al-Māliyyah al-Islāmiyyah alUrdūniyyah li al-Mi’yar al-Muḥāsibī al-Islāmī al-Murābaḥah wa al-Murābaḥah al-Amīr bi al-Shirā',' (Master Dissertation, al-Bayt University, 2008), Raqm 2, 28.

10 Yāsīn Karamatullah Makhdum, 'Muștalaḥ (al-Qawl al-Gharīb) fī al-Fiqh: Mafhūmuhu wa Ḍābițuhu wa Āthāruhu fī Naql al-Khilāf al-Fiqhi wa al-Futya Dirāsah Istiqra'iyyah Muqāranah,' Majallat al-Jam 'īyah al-Fiqhīyah al-Sa 'ūdìyah, vol. 19 (2014), 313.

11 Maszlee Malik, Talfiq: Beramal dengan Pelbagai Mazhab (Shah Alam: Karya Bestari Sdn. Bhd., 2005), 11.

12 Abdullah@Alwi Hassan, 'Ijtihad dan Peranannya dalam Pengharmonian Pengamalan Undang-Undang Syariah di Dunia Islam Masa Kini,' Jurnal Syariah, vol. 15/2 (2007): 7.

13 Haim Gerber, 'Rigidity versus Openness in Late Classical Islamic Law: The Case of the Seventeenth-Century Palestinian Muftī Khayr al-Dīn al-Ramlī,' Islamic Law and Society, vol. 5/2 (1998): 173.

14 Butti Sultan Butti Ali al-Muhairi, 'Conclusion to the Series of Articles on the UAE Penal Law,' Arab Law Quarterly, vol. 12/4 (1997): 392.

15 Ibrahim, Y. S., 'The Spirit of Islamic Law and Modern Religious Reform: Maqasid al-Shari'a in Muhammad 'Abduh and Rashid Rida's Legal Thought' (Ph.D Thesis, Princeton University, New Jersey, United States of America, 2004), 138. 
bersesuaian dengan tuntutan semasa. ${ }^{16}$ Fazlur Rahman pula menyatakan sekiranya penggunaan pandangan satu mazhab semata-mata akan menyebabkan kesusahan dan kesempitan, penggunaan pandangan mazhab yang lain perlu dilakukan dengan tujuan untuk memberi kemudahan kepada orang ramai. Beliau menjelaskan bahawa perkara ini merupakan satu bentuk pembaharuan melalui pegangan golongan tradisionalis yang dikenali sebagai talfiq. ${ }^{17}$ Takriftakrif di atas banyak digunakan oleh pengkaji yang menjalankan penyelidikan berkenaan golongan modenis dan reformis Muslim termasuklah Mohammad Hashim Kamali. ${ }^{18}$

Sebahagian pengkaji pula merujuk kepada takrif al-Zuhaylī bagi memberikan satu takrif talfiq yang agak terperinci. ${ }^{19}$ Anisah Ab. Ghani dan lain-lain menjelaskan konsep talfiq berdasarkan takrif yang dikemukakan oleh al-Zuhaylī sebagai menghimpunkan antara taqlid dua imam atau lebih dalam satu perbuatan di mana setiap perbuatan itu mempunyai rukun dan juz'iyyāt yang mempunyai hubungan antara satu sama lain. Setiap perbuatan itu juga mempunyai hukum yang khas yang menjadi pokok perselisihan dalam kalangan ulama. Apabila seseorang bertaqlid kepada mazhab tertentu dalam sesuatu hukum dan bertaqlid kepada mazhab yang lain dalam satu hukum yang lain, maka perbuatan itu dianggap talfiq di antara dua mazhab atau lebih. ${ }^{20}$ Takrif ini boleh dikatakan sebagai takrif yang agak terperinci bagi menjelaskan maksud sebenar berkenaan konsep talfiq. Walau bagaimanapun, takrif seperti ini mungkin boleh dikritik kerana ia terlalu panjang bagi menjelaskan maksud sebenar konsep talfiq. Ini boleh menyebabkan ia terkeluar daripada bentuk 'takrif' kepada bentuk 'penjelasan' yang panjang lebar berkenaan konsep

16 R. Michael Feener, 'Indonesian Movements for the Creation of a National Madhhab,' Islamic Law and Society, vol. 9/1 (2002): 95 \& 96.

17 Fazlur Rahman, 'Islamic Method Modernism: Its Scope, Method and Alternative,' International Journal of Middle East Studies, vol. 1/4 (1970): 325.

18 Mohammad Hashim Kamali, 'Shari'ah and Civil Law: Towards A Methodology of Harmonization,' Islamic Law and Society, vol. 14/3 (2007): 408.

19 Wahbah al-Zuhaylī, al-Rukhaș al-Shar 'iyyah (Bayrūt: Dār al-Khayr, 1993), 56.

20 Anisah Ab. Ghani et al., 'Penerimaan Masyarakat Islam di Malaysia Terhadap Amalan Percampuran Mazhab di Malaysia,' Jurnal Fiqh, vol. 4 (2007): 199 \& 200 . 
talfiq. Takrif ini turut disebut oleh beberapa pengkaji yang lain seperti Safwan Ali 'Udaybat, ${ }^{21}$ dan Muḥammad Faḍīl Muṣțafā. ${ }^{22}$

\section{Jadual 1: Bentuk-Bentuk Takrif yang Dikemukakan bagi Menjelaskan Talfiq}

\begin{tabular}{|c|c|c|}
\hline Bil. & Penulis & Bentuk Takrif Yang Dikemukakan \\
\hline 1. & $\begin{array}{l}\text { Al-Bani (1997); Krawietz } \\
\text { (2002); Layish (2004); } \\
\text { Ayah 'Abd al-Salam } \\
\text { (2006); al-Syaihan, } \\
\text { (2008); Muhammad } \\
\text { Ahmad Mustarihi (2012); } \\
\text { al-Khaylah (2008); Yasin } \\
\text { Karamatullah Makhdum } \\
\text { (2014); Maszlee Malik } \\
\text { (2005) }\end{array}$ & $\begin{array}{l}\text { Takrif-takrif yang lebih cenderung kepada } \\
\text { takrif yang dikemukakan oleh al-Bani sebagai } \\
\text { satu takrif yang masyhur dan diterima oleh } \\
\text { sebahagian besar pengkaji bagi konsep talfiq. }\end{array}$ \\
\hline 2. & $\begin{array}{l}\text { Abdullah@Alwi Hassan } \\
\text { (2007); Haim Gerber } \\
\text { (1998); Al-Muhairi (1997); } \\
\text { Y. S. Ibrahim (2004) }\end{array}$ & $\begin{array}{l}\text { Bentuk takrif yang agak longgar dengan hanya } \\
\text { memfokuskan kepada percampuran mazhab. }\end{array}$ \\
\hline 3. & $\begin{array}{l}\text { Michael Feener (2002); } \\
\text { Fazlur Rahman (1970); } \\
\text { Kamali (2007) }\end{array}$ & $\begin{array}{l}\text { Takrif yang lebih memberi perhatian terhadap } \\
\text { tujuan penggunaan konsep talfiq iaitu untuk } \\
\text { memberikan kemaslahatan kepada manusia. }\end{array}$ \\
\hline 4. & $\begin{array}{l}\text { al-Zuhaylī (1986); } \\
\text { Anisah Ab. Ghani et. al. } \\
\text { (2007); 'Udaybat (2012); } \\
\text { Muhạammad Faḍīl Muștafāa } \\
\text { (1998) }\end{array}$ & Penjelasan secara terperinci bagi konsep talfiq. \\
\hline
\end{tabular}

Sumber: Penyelidikan

Perbezaan dari sudut bentuk-bentuk takrif ini adalah berpunca daripada pemahaman yang berbeza terhadap konsep talfiq itu sendiri. Ini kerana, masih berlaku kekeliruan di antara konsep taqlid dan talfiq. Talfiq sekalipun dianggap sebahagian daripada taqlid, tetapi ia sebenarnya lebih khusus daripada taqlid. Justeru, para pengkaji yang mengemukakan takrif talfiq yang agak longgar

21 Șafwan Muhammad Riḍā' 'Alī 'Udaybat, 'al-Tarakhkhus fī Masā'il al-Ikhtilāf fī al-Fiqh al-Islāmī: Dirāsah Ta'siliyyah Tațbīqiyyah-Masā'il Mu'āmalāt fì Qarārāt Majma“ al-Fiqh al-Islāmī fī Jaddah Anmudhajan,' (Ph.D Thesis, The World Islamic Sciences and Education University, Jordan, 2012), 66.

22 Muḥammad Faḍīl Mușțafā, 'al-Talfĩq bayna al-Madhāhib wa Athāruhu fĩ al-Fiqh al-Islāmī', (Ph.D Thesis, International Islamic University Malaysia, 1998), 12. 
berpandangan bahawa talfiq boleh berlaku dengan semata-mata menggunakan pandangan daripada mazhab-mazhab yang berbeza. Manakala, para pengkaji yang lebih teliti meletakkan syarat yang jelas bahawa talfiq hanya berlaku apabila percampuran pandangan beberapa mazhab telah menyebabkan hukum yang dikeluarkan daripadanya tidak diiktiraf oleh mana-mana mazhab terdahulu. Selain itu, terdapat juga takrif yang menjelaskan tentang tujuan penggunaan konsep talfiq. Walau bagaimanapun, ia tidak popular dalam kalangan para pengkaji kerana takrif-takrif seperti ini masih tidak menjelaskan unsur-unsur penting bagi konsep talfiq seperti penggabungan pandanganpandangan mazhab dan pengeluaran satu hukum yang baru.

Perbahasan berkenaan maksud sebenar bagi konsep talfiq ini adalah penting kerana berlaku banyak kekeliruan berkenaan konsep talfiq dengan beberapa istilah yang lain. Amalan percampuran mazhab seperti mana yang dibincangkan di dalam ilmu usul fiqh adalah melalui beberapa bentuk iaitu talfiq, takhayyur (kebebasan individu untuk memilih mana-mana pendapat mazhab dan tidak terikat dengan satu mazhab fizh sahaja), ${ }^{23}$ tatabbu' al-rukhas (Mengambil pendapat yang paling ringan dalam sesuatu permasalahan tanpa mengambil kira pandangan yang rajih) ${ }^{24}$ dan tarjīh (menguatkan salah satu dalil daripada dalil yang lain dengan satu perkara yang tidak zahir). ${ }^{25}$ Kekeliruan berkenaan dengan istilah-istilah ini telah menyebabkan sebahagian ulama menyamakan pengertian sebahagiannya dengan sebahagian yang lain sedangkan kesemua istilah tersebut mempunyai maksud dan makna yang tersendiri. Sebagai contoh Muhammad bin Ahmad al-Safarini pernah menyamakan pengertian talfiq dengan tatabbu' al-rukhas. Yusuf al-Qaradawi pula telah mengemukakan satu definisi talfiq yang menyerupai dengan pengertian bagi konsep tarjī $h .{ }^{26}$ Selain itu, talfiq juga perlu dibezakan dengan taqlid, perpindahan mazhab, mura 'àt al-khiläf dan pengeluaran pendapat ketiga. ${ }^{27}$

23 Maszlee Malik, Talfìq: Beramal dengan Pelbagai Mazhab, 11 \& 12.

24 Badr al-Dīn Muḥammad bin Bahadur al-Zarkashī, al-Bahr al-Muhit, vol. 6 (Hurghada: Dār al-Șafwah, 1992), 130.

25 Khālid bin Musa'id al-Ruwayti', al-Tamadhhub, vol. 2 (Riyāḍ: Dār alTadmūriyyah, 2013), 994.

26 Anisah Ab. Ghani et al., 'Penerimaan Masyarakat Islam di Malaysia Terhadap Amalan Percampuran Mazhab di Malaysia,' 199.

27 Al-'Ațibī, G. bin M., 'al-Talfīq bayn al-Madhāhib al-Fiqhiyyah wa 'Alaqātuhu bi Taysīr al-Fatwā,' (Garis Panduan Fatwa anjuran al-Majma' al-Fiqh al-Islāmī, Arab Saudi, Makkah, 17-20 Januari 2009); Al-Sa'idī, A. bin M., 'al-Talfĩq wa Hukmuhu fì al-Fiqh al-Islāmī,' (Garis Panduan Fatwa anjuran al-Majmā‘ al-Fiqh al-Islāmī, Arab Saudi, Makkah, 17-20 Januari 2009). 


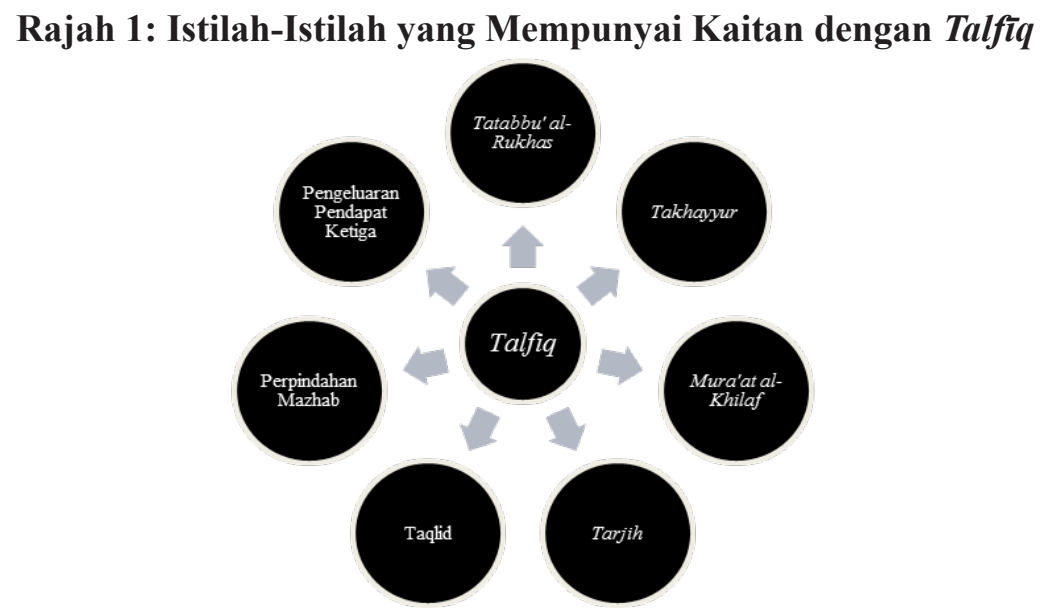

Sumber: Penyelidikan

Rentetan daripada itu, para pengkaji berkenaan konsep talfiq gemar untuk menjelaskan konsep-konsep di atas yang dianggap mempunyai maksud yang hampir sama dengan talfí dan berkemungkinan menyebabkan berlaku kekeliruan. Penekanan yang lebih diberikan dalam menyatakan perbezaan di antara talfiq dan tatabu' al-rukhas kerana kedua-dua istilah kerap di salah tafsir sehingga dianggap sebagai satu konsep yang sama. Ini boleh dilihat di dalam kajian yang dibuat oleh 'Udaybat, ${ }^{28}$ Khalid bin Musa'id al-Ruwayti' ${ }^{29}$ Maszlee Malik ${ }^{30}$ dan Muḥammad Faḍīl Muștafā. ${ }^{31}$

\section{PERBINCANGAN PARA ULAMA BERKENAAN TALFĪ $Q$}

Para pengkaji juga turut menyentuh berkenaan sejarah bermulanya perkembangan konsep talfiq. Para pengkaji berselisih pendapat berkenaan bilakah berlakunya perbincangan berkenaan konsep talfiq dalam kalangan para ulama. Perkara yang pasti, istilah talfiq tidak pernah diperkatakan sebelum penghujung kurun keempat hijrah. ${ }^{32}$ Tidak pernah tercatat juga perbincangan

28 Șafwan Muhammad Riḍā' 'Alī 'Udaybat, 'al-Tarakhkhus fī Masā'il al-Ikhtilāf fī al-Fiqh al-Islāmī: Dirāsah Ta’siliyyah Tațbīqiyyah-Masā’il Mu'āmalāt fì Qarārāt Majma‘ al-Fiqh al-Islāmī fī Jaddah Anmudhajan,' 79.

29 Khālid bin Musa'id al-Ruwayti', al-Tamadhhub, vol. 2, 1090-1091.

30 Maszlee Malik, Talfiq: Beramal dengan Pelbagai Mazhab, 37-47.

31 Muḥammad Faḍīl Mușṭafā, 'al-Talfīq bayna al-Madhāhib wa Athāruhu fĩ al-Fiqh al-Islāmī,' 28-39.

32 Krawietz, B., 'Cut and Paste in Legal Rules: Designing Islamic Norms with Talfiq,' 11. 
berkenaan konsep talfiq di dalam kitab-kitab para imam mazhab dan kitabkitab para $a s ̣ h \bar{a} b$ (pengikut-pengikut utama) bagi imam-imam mazhab. ${ }^{33}$ Pada penghujung kurun keempat hijrah, gejala taqlid kepada satu mazhab sahaja telah makin menebal. Ini kerana selepas zaman imam-imam mazhab, fokus pengajian ilmu fiqh telah beralih kepada satu bentuk yang baru. Para penuntut ilmu fiqh amat mengambil berat untuk menulis semula dan memelihara segala hukum-hukum dan kaedah-kaedah yang dikeluarkan oleh imam mazhab masing-masing. Hasil daripada penulisan-penulisan ini telah membawa kepada kecenderungan untuk bermazhab dengan mazhab imam masing-masing. Setiap mazhab pula mempunyai pengikut dan pendokong tersendiri yang sentiasa berkhidmat untuk mengukuhkan mazhab yang dipegangnya. Ini menyebabkan sesetengah mazhab tersebut menjadi sangat tersusun dan memudahkan para pengikutnya untuk mengikuti dan mempelajari segala hukum yang ditetapkan di dalam sesebuah mazhab tersebut. Walau bagaimanapun, pengukuhan mazhab-mazhab ini khususnya empat mazhab yang utama iaitu mazhab Hanafī, Mālikī, Shāfi‘'̄ dan Hanbalī telah menyebabkan peranan para ulama fiqh untuk berijtihad dalam mengeluarkan sesuatu hukum telah berubah sedikit demi sedikit kepada sifat taqlid dan jumud terhadap pandangan yang dikeluarkan oleh para imam mazhab mereka semata-mata. ${ }^{34}$

Terdapat pandangan yang mengatakan amalan talfiq telah bermula seawal kurun kelima hijrah. ${ }^{35}$ Ini kerana, pada ketika itu sifat taksub kepada sesuatu mazhab telah semakin menebal. Selain itu, faktor politk turut memainkan peranan kerana terdapat pemerintah yang mewajibkan rakyatnya supaya hanya berpegang kepada satu mazhab tertentu. ${ }^{36}$ Pada kurun kelima juga tersebar pandangan yang mengatakan pintu ijtihad telah tertutup. Hasil kepada sikap taksub kepada mazhab tertentu, para ulama mula meletakkan syarat-syarat yang ketat untuk bertaqlid dengan sesuatu mazhab. Setelah itu, timbullah istilah talfiq, dengan peletakan syarat dalam kalangan para ulama mazhab bagi seseorang ingin bertaqlid kepada mazhab yang lain perlu memastikan bahawa ia tidak membawa kepada amalan talfiq. ${ }^{37}$ Walau bagaimanapun, masih

33 Āyah 'Abd al-Salām, 'al-Talfìq wa Tatabbu' al-Rukhaṣ wa Taṭ̣īqātuhu fī al'Ibādat wa al-Aḥwāl al-Shakhsiyyah,' 63.

34 Muhammad Faḍīl Mușṭafā, 'al-Talfĩq bayna al-Madhāhib wa Athāruhu fī al-Fiqh al-Islāmī,' 24 \& 25; Maszlee Malik, Talfìq: Beramal dengan Pelbagai Mazhab, 15.

35 Krawietz, B., 'Cut and Paste in Legal Rules: Designing Islamic Norms with Talfiq,' 11.

36 Āyah 'Abd al-Salām, 'al-Talfìq wa Tatabbu' al-Rukhaṣ wa Taṭbīqātuhu fì al'Ibādat wa al-Aḥwāl al-Shakhsiyyah,' 63.

37 Muḥammad Faḍīl Muṣțafā, 'al-Talfĩq bayna al-Madhāhib wa Athāruhu fĩ al-Fiqh al-Islāmī', 22. 
terdapat pandangan yang mengatakan talfiq tidak pernah diperbincangkan oleh para ulama sebelum daripada kurun ketujuh hijrah. Manakala, pada kurun kesepuluh hijrah barulah timbul pandangan ulama yang mengatakan bahawa amalan talfiq perlu dielakkan sebagai salah satu syarat untuk bertaqlid kepada pandangan mazhab yang lain. ${ }^{38}$

Kajian-kajian berkenaan sejarah talfiq ini menunjukkan bahawa amalan talfiq bermula hasil daripada beberapa sikap negatif dalam kalangan ulama pada waktu tersebut seperti sikap taksub, jumud dan lain-lain. Justeru itu, kebanyakan kajian-kajian terkini berkenaan konsep talfiq lebih menjurus kepada pandangan yang membenarkan talfiq dan menolak pandangan ulama silam yang melarang penggunaan talfiq ketika bertaqlid. Ini bertujuan untuk menolak sikap-sikap negatif tersebut daripada merebak kepada masyarakat muslim moden pada masa kini. Antara pengkaji yang membenarkan penggunaan konsep talfiq ini adalah seperti Ibrahim, ${ }^{39}$ Michael Feener, ${ }^{40}$ Șafiyyah 'Alī al-Shar', ${ }^{41}$ al-'Anzi, ${ }^{42}$ Abdullah@Alwi, ${ }^{43}$ Anisah Ab. Ghani dan lain-lain, ${ }^{44}$ Maszlee Malik ${ }^{45}$ dan Muhammad Faḍîl Mușțafā. ${ }^{46}$

Walau bagaimanapun, masih ramai sebenarnya pengkaji-pengkaji terkini yang cenderung kepada pandangan sebahagian besar ulama silam yang melarang penggunaan talfíq. Antara pengkaji-pengkaji tersebut adalah Inarah

38 Krawietz, B., 'Cut and Paste in Legal Rules: Designing Islamic Norms with Talfí,' 12; Maszlee Malik, Talfiq: Beramal dengan Pelbagai Mazhab, 15.

39 Ibrahim, Y. S., 'The Spirit of Islamic Law and Modern Religious Reform: Maqasid al-Shari'a in Muhammad 'Abduh and Rashid Rida's Legal Thought,' 138.

40 R. Michael Feener, 'Indonesian Movements for the Creation of a National Madhhab,' 97.

41 Șafiyyah 'Alī al-Shar', 'Tatabbu' al-Rukhaș, Dirāsah Naqdiyyah li Ra'y al-Imām al-Shāțibī', Majallah Jami'ah al-Shariqah li al-'Ulūm al-Shar'iyyah wa alQanūniyyah, vol. 11/1 (2014), 177.

$42 \quad$ Sa'ad al-'Anzī, 'al-Talfīq fī al-Fatawā,' 285.

43 Abdullah@Alwi Hassan, 'Ijtihad dan Peranannya dalam Pengharmonian Pengamalan Undang-Undang Syariah di Dunia Islam Masa Kini,' 11-13.

44 Anisah Ab. Ghani et al., 'Penerimaan Masyarakat Islam di Malaysia Terhadap Amalan Percampuran Mazhab di Malaysia,' 203 \& 204.

45 Maszlee Malik, Talfiq : Beramal dengan Pelbagai Mazhab, 95-100.

46 Muḥammad Faḍīl Mușțafā, 'al-Talfĩq bayna al-Madhāhib wa Athāruhu fī al-Fiqh al-Islāmī', 60 . 
Ahmad Farid dan Saadan Man, ${ }^{47}$ Samuela Pagani, ${ }^{48}$ Fareeha Khan, ${ }^{49}$ Saminaz Zaman, ${ }^{50}$ Aharon Layish, ${ }^{51}$ Tawfīq Aḥmad al-Ghalbazūrī ${ }^{52}$ dan Sulayman alSyaihan. ${ }^{53}$

\section{DALIL-DALILBAGIPENYOKONGDANPENENTANGPENGGUNAAN KONSEP TALFIQ}

Kedua-dua golongan sama ada yang menyokong atau menentang penggunaan konsep talfiq mempunyai hujah-hujah bagi menyokong pandangan mereka. Sebahagian hujah yang menjadi sandaran bagi golongan yang membenarkan penggunaan konsep talfiq adalah merujuk kepada sepotong ayat di dalam alQuran sebagaimana berikut:

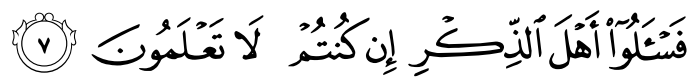

"Maka bertanyalah kamu kepada Ahl al-Zikr jika kamu tidak mengetahui."

(Surah al-Anbiyā', 21:7)

Ayat di atas membenarkan seseorang untuk bertanya berkenaan hukum hakam syarak kepada sesiapa yang dikehendaki daripada kalangan ulama sama ada para ulama tersebut pada martabat yang sama mahupun berbeza. ${ }^{54}$ Selain itu, golongan yang membenarkan talfiq turut bersandarkan kepada

47 Inarah Ahmad Farid \& Saadan Man, 'Keterbukaan Bermazhab dalam Realiti di Malaysia: Keperluan atau Kecelaruan?,' Jurnal Syariah, vol. 20/3 (2012): 297.

48 Samuela Pagani, 'The Meaning of the Ikhtilaf al-Madhahib in Abd al-Wahhab alSha'rani's al-Mizan al-Kubra,' Islamic Law and Society, vol. 11/2 (2004): 187.

49 Fareeha Khan, 'Traditionalist Approaches to Shariah Reform: Mawlana Ashraf Ali Thanawi Fatwa on Women Right to Divorce,' (Ph.D Thesis, The University of Michigan, USA, 2008), 61.

50 Saminaz Zaman, 'Amrikan Shari'a: The Reconstruction of Islamic Family Law in the United States,' South Asia Research, vol. 28/2 (2008): 191.

51 Layish, A., 'The Transformation of the Sharī'a from Jurists' Law to Statutory Law in the Contemporary Muslim World,' Die Welt Des Islams, vol. 44/1 (2004): 94.

52 Tawfīq Aḥmad al-Ghalbazūrī, 'al-Fatwā al-Mu'āsirah bayna al-Indibāt wa alIdtirāb: al-Fatawā al-Shazzah Namūzajan,' Majallah al-Mudawwanah, vol. 3 (2014), 211.

53 Sulayman Yūsuf al-Shayhan, 'al-Fatwā fī al-Urdun Tarīkhan wa Fiqhan wa Manhajan,' 49.

54 Muḥammad Faḍīl Muștafā, 'al-Talfĩq bayna al-Madhāhib wa Athāruhu fī al-Fiqh al-Islāmī,' 42; Maszlee Malik, Talfìq: Beramal dengan Pelbagai Mazhab, 63. 
kepentingan dan maslahat umum, ${ }^{55}$ tuntutan semasa, ${ }^{56}$ pendedahan kepada kepelbagaian mazhab, ${ }^{57}$ ketiadaan dalil yang melarang penggunaan talfiq $^{58}$ dan asal sesuatu perkara adalah harus. ${ }^{59}$

Hujah lain yang turut digunakan bagi membenarkan penggunaan talfiq adalah amalan talfíq ini merupakan amalan yang sering dilakukan oleh masyarakat muslim terdahulu sekitar tiga kurun hijrah yang pertama daripada kalangan para sahabat, tabi'in dan para imam mujtahid. ${ }^{60}$ Selain itu, tidak terdapat sebarang nas daripada para sahabat yang melarang untuk bertalfiq dan mencampur adukkan pandangan dalam kalangan para sahabat ini. Bahkan

55 Abdullah@Alwi Hassan, 'Ijtihad dan Peranannya dalam Pengharmonian Pengamalan Undang-Undang Syariah di Dunia Islam Masa Kini,'12; Ibrahim, Y. S., 'The Spirit of Islamic Law and Modern Religious Reform: Maqasid al-Shari'a in Muhammad 'Abduh and Rashid Rida's Legal Thought,' 141; Āyah 'Abd alSalām, 'al-Talfīq wa Tatabbu' al-Rukhaṣ wa Taṭbīqātuhu fī al-'Ibādat wa al-Aḥwāl al-Shakhsiyyah,' 73-78; Șafwan Muhammad Riḍā' 'Alī 'Udaybat, 'al-Tarakhkhus fī Masā'il al-Ikhtilāf fī al-Fiqh al-Islāmī: Dirāsah Ta'siliyyah Taṭbīqiyyah-Masā'il Mu'āmalāt fī Qarārāt Majma‘ al-Fiqh al-Islāmī fī Jaddah Anmudhajan,' 73; Sa'ad al- 'Anzīi, 'al-Talfīq fī al-Fatawā,' 288; Nașīr 'Abd Allāh al-Mayman, 'al-Talfīq fi al-Ijtihād wa al-Taqlid,' al-Nawāzil al-Tashri 'iyyah (Al-Dammam: Dār Ibn alJawzī, 2008), 17; Maszlee Malik, Talfíq: Beramal dengan Pelbagai Mazhab, 6374.

56 Anisah Ab. Ghani et al., 'Penerimaan Masyarakat Islam di Malaysia Terhadap Amalan Percampuran Mazhab di Malaysia,' 198; Ibrahim, Y. S., 'The Spirit of Islamic Law and Modern Religious Reform: Maqasid al-Shari'a in Muhammad 'Abduh and Rashid Rida's Legal Thought,' 140 \& 141. Krawietz, B., 'Cut and Paste in Legal Rules: Designing Islamic Norms with Talfiq,' 3; Sa'ad al-'Anzī, 'al-Talfìq fī al-Fatawā,' 288.

57 Anisah Ab. Ghani et al., 'Penerimaan Masyarakat Islam di Malaysia Terhadap Amalan Percampuran Mazhab di Malaysia,' 198; Șafiyyah 'Alī al-Shar', 'Tatabbu' al-Rukhaṣ, Dirāsah Naqdiyyah li Ra’y al-Imām al-Shāțibī', 177.

58 Șafwan Muhammad Riḍā' 'Alī 'Udaybat, 'al-Tarakhkhus fĩ Masā'il al-Ikhtilāf fī al-Fiqh al-Islāmī: Dirāsah Ta'siliyyah Taṭbīqiyyah-Masā’il Mu‘āmalāt fī Qarārāt Majma' al-Fiqh al-Islāmī fì Jaddah Anmudhajan,' 74; Nașīr 'Abd Allāh alMayman, 'al-Talfĩq fi al-Ijtihād wa al-Taqlid,' 17; Maszlee Malik, Talfìq: Beramal dengan Pelbagai Mazhab, 63-74; Muhammad Faḍil Mușțafā, 'al-Talfĩq bayna alMadhāhib wa Athāruhu fī al-Fiqh al-Islāmī', 44.

59 Khālid bin Musa'id al-Ruwayti', al-Tamadhhub, vol. 2, 1080.

60 Ibrahim, Y. S., 'The Spirit of Islamic Law and Modern Religious Reform: Maqasid al-Shari'a in Muhammad 'Abduh and Rashid Rida's Legal Thought,' 140; Șafwan Muḥammad Rị̣ā' 'Alī 'Udaybat, 'al-Tarakhkhus fì Masā'il al-Ikhtilāf fī al-Fiqh al-Islāmī: Dirāsah Ta'siliyyah Taṭbīqiyyah-Masā’il Mu'āmalāt fī Qarārāt Majma‘ al-Fiqh al-Islāmī fì Jaddah Anmudhajan,' 74; Sa'ad al-'Anzī, 'al-Talfīq fī alFatawā,' 287. 
orang awam, bebas untuk meminta fatwa dan mengikut mana-mana pandangan yang diberikan oleh para sahabat Nabi S.A.W. ${ }^{61}$ Seterusnya, golongan yang membenarkan talfiq juga berhujah dengan mengatakan talfiq adalah taqlid. Oleh itu, sekiranya taqlid dibenarkan sehingga ke tahap diwajibkan kepada muqallid, maka talfí juga hendaklah diharuskan kerana kedua-duanya adalah sama. ${ }^{62}$

\section{Rajah 3: Sebahagian Dalil-Dalil yang dikemukakan oleh para penulis bagi menyokong penggunaan Talfíq}

\section{Dalil-Dalil bagi Golongan yang Menyokong Penggunaan Talfiq}

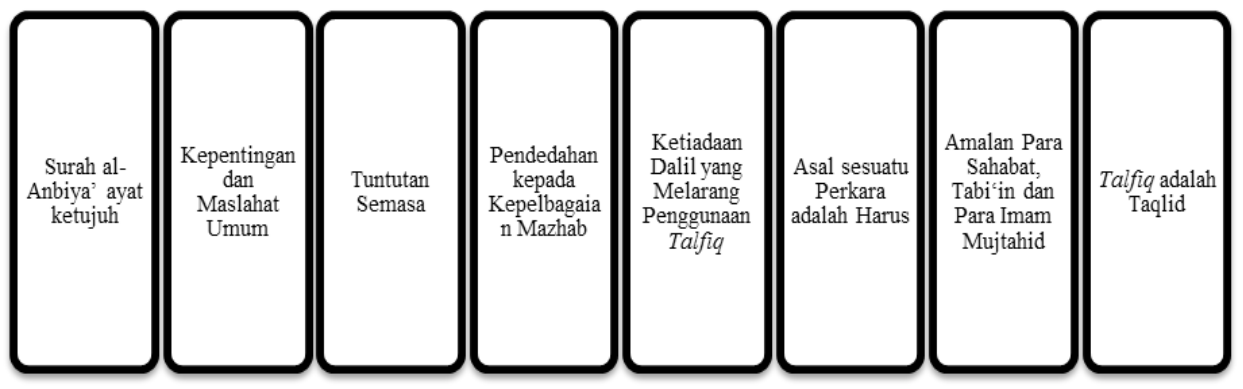

Sumber: Penyelidikan

Adapun golongan yang berpandangan bahawa talfiq tidak dibenarkan, mereka berhujahkan bahawa penggunaan konsep talfiq akan membawa kerosakan kepada agama. Antara kerosakan tersebut adalah orang awam yang tidak mempunyai autoriti akan cuba menyelesaikan permasalahan mereka sendiri tanpa merujuk kepada para ulama. Persoalan agama pada ketika itu tidak lagi diselesaikan oleh para ulama, bahkan ia boleh diselesaikan oleh orang awam yang tiada kepakaran dalam bidang Syariah. ${ }^{63}$ Penggunaan talfiq

${ }^{61} \quad$ Khālid bin Musa'id al-Ruwayti', al-Tamadhhub, vol. 2, 1080; Nașīr 'Abd Allāh alMayman, 'al-Talfĩq fi al-Ijtihād wa al-Taqlid,' 16; Maszlee Malik, Talfìq: Beramal dengan Pelbagai Mazhab, 63-74. Muhammad Faḍīl Mușțafā, 'al-Talfĩq bayna alMadhāhib wa Athāruhu fī al-Fiqh al-Islāmī', 43.

62 Nașīr 'Abd Allāh al-Mayman, 'al-Talfĩq fi al-Ijtihād wa al-Taqlid,' 16; Āyah 'Abd al-Salām, 'al-Talfĩq wa Tatabbu' al-Rukhaș wa Taṭbīqātuhu fī al-'Ibādat wa alAḥwāl al-Shakhsiyyah,' 73.

63 Indira Falk Gesink, 'Islamic Reformation: A History of Madrasa Reform and Legal Change in Egypt,' Comparative Education Review, vol. 50/3 (2006): 339; Āyah 'Abd al-Salām, 'al-Talfĩq wa Tatabbu' al-Rukhas wa Taṭbīqātuhu fĩ al-'Ibādat wa al-Aḥwāl al-Shakhsiyyah,' 68 \& 69. 
juga akan membawa kepada keinginan untuk mempermain-mainkan agama dengan meninggalkan penggunaan dalil dan beralih kepada segala perselisihan pendapat dalam kalangan mazhab. Manakala, perkara yang diharamkan secara jelas dengan nas syarak akan menjadi halal dengan penggunaan talfiq seperti meminum arak dan melakukan zina. ${ }^{64}$

Penggunaan talfiq seterusnya akan menyebabkan seseorang memilih manamana pandangan mazhab berdasarkan kehendak nafsunya semata-mata. ${ }^{65}$ Sebahagian pengkaji pula berpandangan penggunaan talfiq boleh dianggap sebagai juristic opportunism ataupun pengambilan kesempatan perundangan. ${ }^{66}$ Pemilihan pandangan seperti ini adalah tidak dibenarkan sekalipun dengan alasan untuk memberi kemudahan dan mengangkat kesulitan daripada masyarakat kerana syarak tidak membenarkan seseorang untuk bertaqlid kepada mazhab-mazhab lain dengan alasan untuk mencari kemudahan sematamata. ${ }^{67}$

Selain daripada itu, antara dalil yang menjadi sandaran golongan yang melarang penggunaan talfiq adalah larangan pengeluaran pandangan ketiga, ${ }^{68}$

64 Șafwan Muhammad Riḍā' 'Alī 'Udaybat, 'al-Tarakhkhus fī Masā’il al-Ikhtilāf fī al-Fiqh al-Islāmī: Dirāsah Ta'siliyyah Taṭbīqiyyah-Masā’il Mu'āmalāt fì Qarārāt Majma‘ al-Fiqh al-Islāmī fī Jaddah Anmudhajan,' 75. Nașīr 'Abd Allāh alMayman, 'al-Talfīq fi al-Ijtihād wa al-Taqlid,' 15; Khālid bin Musa'id al-Ruwayti', al-Tamadhhub, vol. 2, 1079; Maszlee Malik, Talfiq: Beramal dengan Pelbagai Mazhab, 55-57.

65 Fareeha Khan, 'Traditionalist Approaches to Shariah Reform: Mawlana Ashraf Ali Thanawi Fatwa on Women Right to Divorce,' 64.

66 Indira Falk Gesink, 'Islamic Reformation: A History of Madrasa Reform and Legal Change in Egypt,' 340; Layish, A., 'The Transformation of the Sharī' a from Jurists' Law to Statutory Law in the Contemporary Muslim World,' 94. Tawfĩq Aḥmad al-Ghalbazūrī, 'al-Fatwā al-Mu'āsirah bayna al-Indibāt wa al-Idtirāb: alFatawā al-Shazzah Namūzajan,' 211.

67 Inarah Ahmad Farid \& Saadan Man, 'Keterbukaan Bermazhab dalam Realiti di Malaysia: Keperluan atau Kecelaruan?', 298.

68 Samuela Pagani, 'The Meaning of the Ikhtilaf al-Madhahib in Abd al-Wahhab alSha'rani's al-Mizan al-Kubra,' 189; Āyah 'Abd al-Salām, 'al-Talfīq wa Tatabbu' al-Rukhaṣ wa Tațbīqātuhu fĩ al-'Ibādat wa al-Aḥwāl al-Shakhsiyyah,' 67; Nūr Shahīrah Muhammad Nașīr, al-Naẓr fĩ Ma'alat al-Af'āl fī al-Ta'amul ma'a alShabakah al-'Ankabūtiyyah: Dirāsah Maqāșidiyyah Tațbīqiyyah,' (Master Dissertation, al-Bayt University, 2013), 41; Maszlee Malik, Talfiq: Beramal dengan Pelbagai Mazhab, 55; Muhammad Faḍīl Mușțafā, 'al-Talfĩq bayna alMadhāhib wa Athāruhu fī al-Fiqh al-Islāmī', 49. 
melanggar ijmak ulama, ${ }^{69}$ hukum yang dikeluarkan tidak diiktiraf oleh mana-mana mazhab ${ }^{70}$ mencabar hak eksklusif mujtahid dalam berijtihad ${ }^{71}$ dan ketiadaan konsistensi di dalam penentuan hukum. ${ }^{72}$ Larangan talfiq juga disandarkan kepada keperluan untuk bermazhab secara teratur dengan mengikut segala peraturan-peraturan yang ditetapkan oleh sesebuah mazhab. Ini kerana, mazhab di dalam Islam khususnya dalam bidang fiqh adalah bertujuan untuk mewujudkan kesatuan dan mengelakkan kecelaruan di dalam masyarakat. ${ }^{73}$

\section{Rajah 4: Sebahagian dalil yang dikemukakan oleh para penulis bagi melarang penggunaan Talfíq}

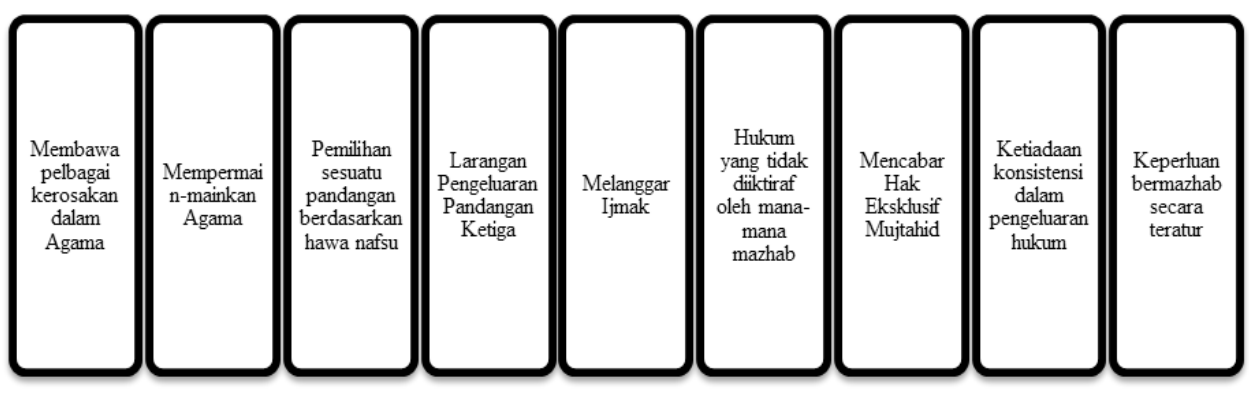

Sumber: Penyelidikan

69 Fareeha Khan, 'Traditionalist Approaches to Shariah Reform: Mawlana Ashraf Ali Thanawi Fatwa on Women Right to Divorce,' 64; Āyah 'Abd al-Salām, 'al-Talfĩq wa Tatabbu' al-Rukhaș wa Tațbīqātuhu fĩ al-'Ibādat wa al-Aḥwāl al-Shakhsiyyah,' 67; Maszlee Malik, Talfiq: Beramal dengan Pelbagai Mazhab, 55-57.

70 Āyah 'Abd al-Salām, 'al-Talfĩq wa Tatabbu' al-Rukhaṣ wa Taṭbīqātuhu fĩ al-'Ibādat wa al-Aḥwāl al-Shakhsiyyah,' 68; Șafwan Muḥammad Riḍā' 'Alī 'Udaybat, 'al-Tarakhkhus fì Masā'il al-Ikhtilāf fì al-Fiqh al-Islāmī: Dirāsah Ta'siliyyah Taṭbīqiyyah-Masā'il Mu'āmalāt fì Qarārāt Majma‘ al-Fiqh al-Islāmī fī Jaddah Anmudhajan,' 75; Khālid bin Musa'id al-Ruwayti', al-Tamadhhub, vol. 2, 1077.

71 Samuela Pagani, 'The Meaning of the Ikhtilaf al-Madhahib in Abd al-Wahhab alSha'rani's al-Mizan al-Kubra,' 188; Indira Falk Gesink, 'Islamic Reformation: A History of Madrasa Reform and Legal Change in Egypt,' 340; Saminaz Zaman, 'Amrikan Shari'a: The Reconstruction of Islamic Family Law in the United States,' 191.

72 Indira Falk Gesink, 'Islamic Reformation: A History of Madrasa Reform and Legal Change in Egypt,' 340; Nașīr 'Abd Allāh al-Mayman, 'al-Talfìq fi al-Ijtihād wa al-Taqlid,' 15.

73 Inarah Ahmad Farid \& Saadan Man, 'Keterbukaan Bermazhab dalam Realiti di Malaysia: Keperluan atau Kecelaruan?’, 297. 


\section{APLIKASI TALFĪQ}

Setelah membincangkan berkenaan takrif dan hukum penggunaan talfiq, para pengkaji turut mengemukakan contoh-contoh penggunaan talfí sama ada daripada penulisan para ulama silam, mahupun aplikasi talfíq dalam permasalahan moden pada masa kini. Antara contoh aplikasi talfíq di dalam penulisan para ulama silam adalah merangkumi permasalahan dalam bab ibadat, ${ }^{74}$ muamalat ${ }^{75}$ dan munakahat. ${ }^{76}$ Contoh permasalahan dalam ibadat adalah seperti seseorang yang berwuduk dengan menggunakan mazhab Shāfi ‘' yang membenarkan menyapu sebahagian kecil daripada kepala. Kemudian, mengikut mazhab Hanafĩ yang mengatakan bahawa menyentuh seseorang yang berlainan jantina adalah tidak membatalkan wuduk. ${ }^{77}$ Contoh permasalahan dalam bab muamalat pula adalah seperti seseorang mengikut mazhab Ḥanafĩ yang mengharuskan syuf'ah jiran untuk memiliki sebidang tanah. Kemudian, apabila dia hendak menjual semula tanah tersebut, dia tidak membenarkan hak syuf'ah ini kepada jirannya dengan bertaqlid kepada mazhab Shāfi'ī yang tidak membenarkan syuf 'ah jiran. ${ }^{78}$ Bagi permasalahan dalam bab munakahat, antara contoh yang diberikan adalah seseorang yang berkahwin tanpa wali dengan bertaqlid kepada mazhab Hanafĩ dan berkahwin tanpa saksi dengan bertaqlid kepada mazhab Mālikī. ${ }^{79}$

74 Lutz Wiederhold, 'Legal Doctrines in Conflict the Relevance of Madhhab Boundaries to Legal Reasoning in the Light of an Unpublished Treatise on Taqlīd and Ijtihād,' Islamic Law and Society, vol. 3/2 (1996): 280 \& 281; Āyah 'Abd alSalām, 'al-Talfīq wa Tatabbu' al-Rukhaṣ wa Taṭbīqātuhu fī al-'Ibādat wa al-Aḥwāl al-Shakhsiyyah,' 139; Muhammad Faḍil Muștafā, 'al-Talfīq bayna al-Madhāhib wa Athāruhu fì al-Fiqh al-Islāmī,' 101.

75 Inarah Ahmad Farid \& Saadan Man, 'Keterbukaan Bermazhab dalam Realiti di Malaysia: Keperluan atau Kecelaruan?', 282 \& 283; Maszlee Malik, Talfíq: Beramal dengan Pelbagai Mazhab, 128-134; Muḥammad Faḍil Mușțafā, 'alTalfĩq bayna al-Madhāhib wa Athāruhu fĩ al-Fiqh al-Islāmī', 99 \& 100.

76 Inarah Ahmad Farid \& Saadan Man, 'Keterbukaan Bermazhab dalam Realiti di Malaysia: Keperluan atau Kecelaruan?', 278, 283, 284; Āyah 'Abd al-Salām, 'al-Talfīq wa Tatabbu' al-Rukhaș wa Taṭbīqātuhu fī al-'Ibādat wa al-Aḥwāl alShakhsiyyah,' 175.

77 Muhammad Faḍ̄i Muștafā, 'al-Talfĩq bayna al-Madhāhib wa Athāruhu fĩ al-Fiqh al-Islāmī', 99.

78 Lutz Wiederhold, 'Legal Doctrines in Conflict the Relevance of Madhhab Boundaries to Legal Reasoning in the Light of an Unpublished Treatise on Taqlīd and Ijtihād,' $282 \& 283$.

79 Āyah 'Abd al-Salām, 'al-Talfīq wa Tatabbu' al-Rukhaṣ wa Taṭbīqātuhu fī al'Ibādat wa al-Aḥwāl al-Shakhsiyyah,' 165-176. 


\section{Rajah 5: Aplikasi Talfíq dalam Permasalahan Klasik}

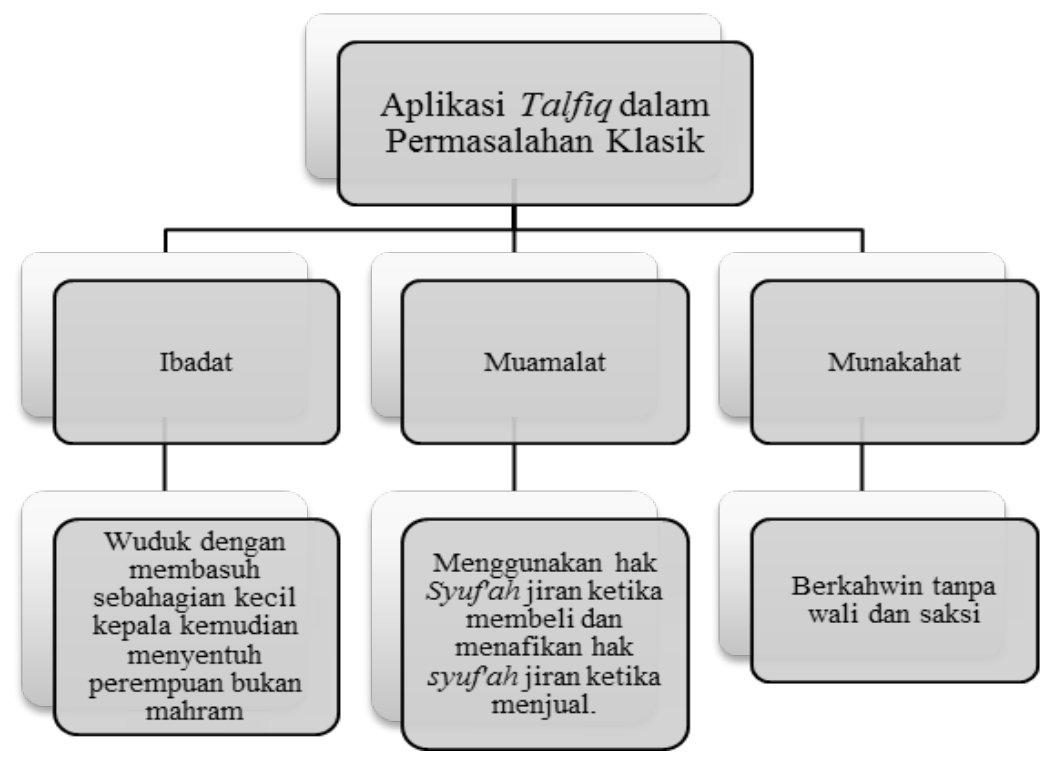

Sumber: Penyelidikan

Adapun aplikasi talfíq pada masa kini, antara contoh yang sering dikemukakan oleh para pengkaji adalah pengkodifikasian undang-undang di negara-negara Islam. ${ }^{80}$ Mohammad Hashim Kamali menjelaskan bahawa talfiq telah digunakan bagi memudahkan usaha untuk mengharmonisasikan di antara perundangan Syariah dan perundangan sivil. ${ }^{81}$ Abdulhamid al-Hargan pula mencadangkan supaya negara Arab Saudi memperkenalkan undangundang bertulis yang komprehensif berdasarkan kepelbagaian pandangan yang terdapat di dalam empat mazhab sunni yang utama. Ia boleh dilakukan dengan menggunakan konsep talfiq di samping memastikan konsistensi

80 Abdullah@Alwi Hassan, 'Ijtihad dan Peranannya dalam Pengharmonian Pengamalan Undang-Undang Syariah di Dunia Islam Masa Kini,' 7; Krawietz, B., 'Cut and Paste in Legal Rules: Designing Islamic Norms with Talfiq,' 3; Wael B. Hallaq, 'Juristic Authority vs State Power: The Legal Crises of Modern Islam,' Journal of Law and Religion, vol. 19/2 (2004): 257; Butti Sultan Butti Ali alMuhairi, 'Conclusion to the Series of Articles on the UAE Penal Law,' 388; Sa'ad al-'Anzī, 'al-Talfĩq fī al-Fatawā,' 286.

81 Mohammad Hashim Kamali, 'Shari'ah and Civil Law: Towards A Methodology of Harmonization,' $391 \& 408$. 
pengkodifikasian undang-undang bertulis tersebut dengan teori perundangan Islam secara umum..$^{82}$

Contoh penggunaan talfiq dalam permasalahan moden juga banyak diberikan dalam permasalahan muamalat seperti dalam permasalahan mushärakah, ${ }^{83}$ muräbahah al-amir bi al-shira ${ }^{\cdot 84}$ dan jual beli harta wakaf. ${ }^{85}$ Terdapat juga contoh permasalahan moden dalam bab ibadat seperti permasalahan pembinaan masjid dengan menggunakan wang zakat fitrah, hukum mengeluarkan zakat fitrah dengan wang, aurat perempuan muslim dan perempuan bukan muslim di asrama ${ }^{86}$ hukum orang yang berwuduk dengan menggunakan air yang terkena najis, hukum menunaikan solat tanpa membaca al-Fatihah dan hukum meninggalkan tawaf qudum dan sa'i di antara Safa dan Marwah dalam ibadah haji. ${ }^{87}$

82 Abdulhamid Abdullah al-Hargan, 'Saudi Arabia and the International Covenant on Civil and Political Rights 1966: A Stalemate Situation,' The International Journal of Human Rights, vol. 9/4 (2005): 497.

83 Nicholas H.D. Foster, 'Islamic Perspectives on the Law of Business Organisations II: The Sharia and Western-style Business Organisations,' European Business Organization Law Review, vol. 11/2 (2010): 292.

84 Muḥammad Aḥmad Mustarihi, 'Ta'amul al-Jam'iyyat al-Ta'awūniyyah alIstithmāriyyah ma‘a al-'Umala al-Dirāsah Fiqhiyyah Muqāranah,' 64; AlKhalaylah, B. M., 'Mada Tațbīq al-Mu'assasah al-Māliyyah al-Islāmiyyah alUrdūniyyah li al-Mi'yar al-Muhāsibī al-Istāmī al-Murābaḥah wa al-Murābaḥah al-Amīr bi al-Shirā',' 28. Muḥammad Faḍīl Mușțafā, 'Al-Talfĩq bayna al-Madhāhib wa Athāruhu fī al-Fiqh al-Islāmī', (Ph.D Thesis, International Islamic University Malaysia, 1998), 105. Maszlee Malik, 'Hukum Talfiq dalam Muamalat: Kajian terhadap Bay ' al-Murābahah li al-Amir bi al-Shira' di Bank Islam Malaysia Berhad (BIMB),' (Disertasi Sarjana, Jabatan Fiqh dan Usul, Akademi Pengajian Islam, Universiti Malaya, Kuala Lumpur, 2004), 208-228.

85 Muḥammad Faḍī Muștafā, 'al-Talfĩq bayna al-Madhāhib wa Athāruhu fĩ al-Fiqh al-Islāmī,' 110.

86 Muḥammad Faḍīl Mușțafā, 'al-Talfĩq bayna al-Madhāhib wa Athāruhu fĩ al-Fiqh al-Islāmī', 101, 106, 109.

87 Āyah 'Abd al-Salām, 'al-Talfìq wa Tatabbu' al-Rukhaṣ wa Taṭbīqātuhu fī al'Ibādat wa al-Aḥwāl al-Shakhsiyyah,' 156 \& 164. 


\section{Rajah 6: Aplikasi Talfĩq dalam Permasalahan Kontemporari}

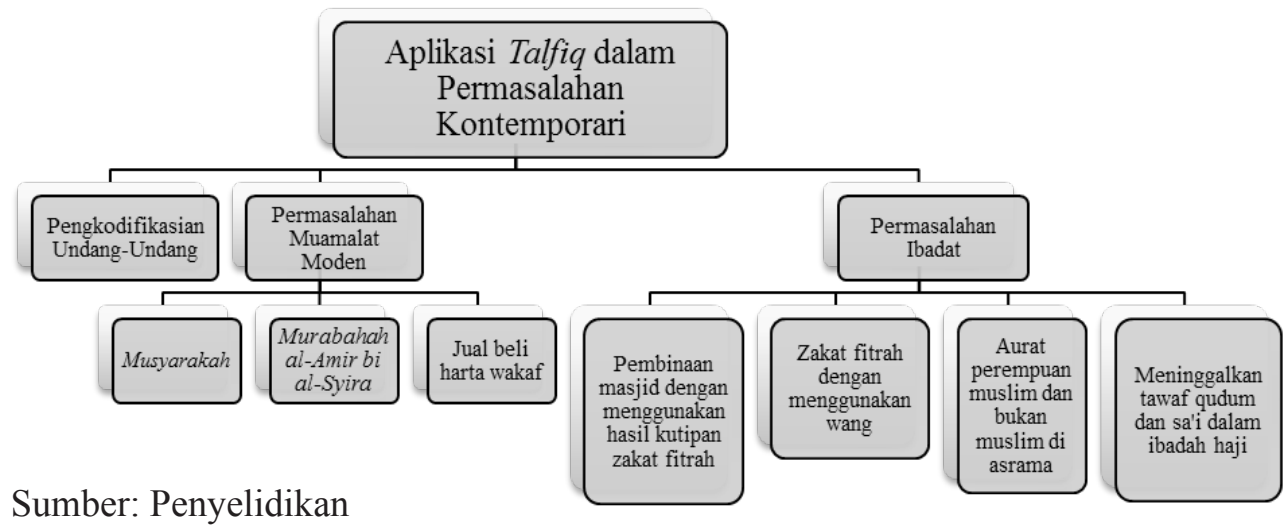

\section{KONSEP PENGAWASAN SYARIAH}

Setelah mengulas kajian-kajian lepas berkenaan konsep talfiq, penyelidik ingin mengulas kajian-kajian yang mempunyai hubungan dengan Majlis Penasihat Syariah Bank Negara Malaysia (MPS BNM) kerana penyelidik telah menggunakan resolusi-resolusi Syariah yang dikeluarkan oleh MPS BNM sebagai sampel bagi menjelaskan bagaimana konsep talfiq telah diaplikasikan pada masa kini. Penyelidik akan mengulas terlebih dahulu kajian-kajian berkenaan konsep pengawasan Syariah dalam sistem kewangan Islam. Konsep pengawasan Syariah telah ditakrifkan sebagai mengawal dan menilai semula (review) aktiviti kewangan yang dilakukan oleh institusi kewangan Islam bagi memastikannya bertepatan dengan hukum Syariat Islam, meneliti perjalanan operasi kewangan dan perbankan, menjelaskan sebarang kesalahan sekiranya ada, dan mencadangkan jalan penyelesaian yang munasabah bagi memperbetulkannya. ${ }^{88}$ Samy Nathan Garas dan Chris Pierce pula mentakrifkan pengawasan Syariah sebagai proses pencegahan, pemulihan dan penyempurnaan bagi mengawal, melakukan review dan menganalisis segala aktiviti, produk, kontrak dan transaksi yang dilakukan oleh institusi-institusi kewangan Islam semenjak daripada penubuhannya lagi. Ini bagi memastikan pematuhan terhadap segala kehendak Syariat Islam dengan tujuan untuk

88 Hayyam Muhạmmad 'Abd al-Qādir al-Zaydaniyyin, 'al-Riqābah al-Shar'iyyah 'ala al-Mașārif al-Islāmiyyah bayna al-Ta'sil wa al-Taṭbīq,' Dirāsāt 'Ulūm alSharī' 'ah wa al-Qānūn, vol. 40/1 (2013): 91. 
mengeluarkan keuntungan yang halal dan menambah baik prestasi institusiinstitusi kewangan Islam. ${ }^{89}$

\section{MAJLIS PENASIHAT SYARIAH BANK NEGARA MALAYSIA (MPS BNM)}

Merujuk kepada MPS BNM secara khusus, ia telah ditubuhkan pada 1 Mei 1997 sebagai pihak berkuasa tertinggi dan rujukan tunggal bagi semua permasalahan berkaitan perbankan Islam dan takaful di Malaysia. Ini memberi kuasa kepada MPS BNM untuk menetapkan segala hukum syarak bagi segala perniagaan perbankan dan kewangan Islam, takaful dan segala perniagaan yang berdasarkan prinsip Syariah yang dikawal selia dan ditadbir oleh Bank Negara Malaysia. ${ }^{90}$ Pihak Jawatankuasa Syariah di peringkat institusiinstitusi kewangan Islam (IKI) pula perlu merujuk kepada MPS BNM bagi segala keputusan yang dibuat di peringkat Jawatankuasa Syariah IKI. Semua keputusan yang dikeluarkan oleh Jawatankuasa Syariah IKI juga perlu dikemukakan kepada perhatian pihak MPS BNM. ${ }^{91}$ Tujuan bagi segala peranan

89 Samy Nathan Garas \& Chris Pierce, 'Shariah Supervision of Islamic Financial Institutions,' Journal of Financial Regulation and Compliance, vol. 18/4 (2010): 388.

90 Grassa, R., 'Shariah Supervisory System in Islamic Financial Institutions, New Issues and Challenges: A Comparative Analysis between Southeast Asia Models and GCC Models,' Humanomics, vol. 29/4 (2013): 340; Mohammad Azam Hussain, Rusni Hassan \& Aznan Hasan, 'Analysis on the Development of Legislations Governing Shariah Advisory Council of Bank Negara Malaysia,' Jurnal Syariah, vol. 23/2 (2015): 326; Hamza, H. (2013). Hamza, H., 'Sharia Governance in Islamic Banks: Effectiveness and Supervision Model,' International Journal of Islamic and Middle Eastern Finance and Management, vol. 6/3 (2013): 233; Adnan Trakic, 'The Adjudication of Shari'ah issues in Islamic Financial Contracts: Is Malaysian Islamic Finance Litigation A Solution?,' Humanomics, vol. 29/4 (2013): 270; Daromir Rudnyckyj, 'From Wall Street to Halal Street: Malaysia and the Globalization of Islamic Finance,' The Journal of Asian Studies, vol. 72/4 (2013): 842; Nooraslinda Abdul Aris, Othman, R., Mohd Azli, R., Sahri, M., Abdul Razak, D., \& Abdul Rahman, Z., 'Islamic Banking Products: Regulations, Issues and Challenges,' Journal of Applied Business Research, vol. 29/4 (2013): 1153; Muhamed Zulkhibri Abdul Majid \& Reza Ghazal, 'Comparative Analysis of Islamic Banking Supervision and Regulation Development,' Money and Economy, vol. 6/3 (2012): 151.

91 Grassa, R., 'Shariah Supervisory Systems in Islamic Finance Institutions Across the OIC Member Countries: An Investigation of Regulatory Frameworks,' Journal of Financial Regulation and Compliance, vol. 23/2 (2015): 154. 
yang dimainkan oleh MPS BNM ini ialah untuk memastikan penyeragaman dan harmonisasi dalam penafsiran Syariah serta memperkukuhkan lagi kerangka pengawal seliaan dan mempromosikan tadbir urus yang baik dalam sektor kewangan Islam. ${ }^{92}$

MPS BNM juga bertindak sebagai pihak pemutus terakhir dalam penafsiran sebarang prinsip Syariah yang berkaitan dengan permasalahan dan amalan perbankan Islam dan takaful di Malaysia. ${ }^{93}$ Pihak mahkamah dan penimbang tara wajib merujuk kepada segala keputusan yang dikeluarkan oleh MPS BNM ataupun mengemukakan persoalan secara terus kepada MPS BNM bagi mendapatkan jawapan berkenaan perkara-perkara yang berkaitan dengan Syariah dan kewangan Islam. Keputusan yang dikeluarkan oleh MPS BNM tersebut adalah mengikat pihak mahkamah dan juga penimbang tara seperti mana yang dinyatakan secara jelas di dalam seksyen 56 dan 57 Akta Bank Negara Malaysia tahun 2009. ${ }^{94}$

Bagi memenuhi tuntutan di atas, sistem kehakiman Malaysia telah memperkenalkan mahkamah khusus untuk mengadili kes-kes kewangan Islam bagi memastikan kes-kes tersebut dapat diuruskan dengan lebih cepat dan efisyen. Mahkamah khusus tersebut berada di bawah Bahagian Muamalat di Mahkamah Tinggi Malaya, Kuala Lumpur yang ditubuhkan pada tahun 2003.

92 Hamza, H., 'Sharia Governance in Islamic Banks: Effectiveness and Supervision Model,' 233; Mohammad Azam Hussain, Rusni Hassan \& Aznan Hasan, 'Analysis on the Development of Legislations Governing Shariah Advisory Council of Bank Negara Malaysia,' 326; Grassa, R., 'Shariah Supervisory Systems in Islamic Finance Institutions Across the OIC Member Countries: An Investigation of Regulatory Frameworks,' 140 \& 146; Arifin Zakaria, 'A Judicial Perspective on Islamic Finance Litigation in Malaysia,' IIUM Law Journal, vol. 21/2 (2013): 174.

93 Hamza, H., 'Sharia Governance in Islamic Banks: Effectiveness and Supervision Model,' 233 \& 154.

94 Mohammad Azam Hussain, Rusni Hassan \& Aznan Hasan, 'Analysis on the Development of Legislations Governing Shariah Advisory Council of Bank Negara Malaysia,' 335 \& 336; Grassa, R., 'Shariah Supervisory System in Islamic Financial Institutions, New Issues and Challenges: A Comparative Analysis between Southeast Asia Models and GCC Models,' 340; Rudnyckyj, 'From Wall Street to Halal Street: Malaysia and the Globalization of Islamic Finance', 842; Nooraslinda Abdul Aris, Othman, R., Mohd Azli, R., Sahri, M., Abdul Razak, D., \& Abdul Rahman, Z., 'Islamic Banking Products: Regulations, Issues and Challenges,' 1153; Muhamed Zulkhibri Abdul Majid \& Reza Ghazal, 'Comparative Analysis of Islamic Banking Supervision and Regulation Development,' 131. 
Bahagian Muamalat di Mahkamah Tinggi Malaya ini terdiri daripada seorang hakim, seorang timbalan pendaftar dan seorang penolong pendaftar kanan. ${ }^{95}$

Manakala, Pusat Timbang Tara Serantau Kuala Lumpur (KLRCA) ${ }^{96}$ telah memainkan peranan dalam menawarkan perkhidmatan profesional bagi menyelesaikan pertikaian dalam kes-kes kewangan Islam melalui jalan timbang tara. KLRCA telah memperkenalkan Kaedah-Kaedah Timbang Tara KLRCA pada tahun 2007 bagi menggalakkan penggunaan timbang tara bagi pertikaian yang berpunca daripada perkhidmatan kewangan Islam. Kaedahkaedah ini telah digantikan dengan kaedah terbaru yang dikenali sebagai Kaedah-Kaedah Timbang Tara-i KLRCA tahun 2013. Kelebihan membawa kes kewangan Islam ke KLRCA berbanding daripada dibawa ke mahkamah ialah keputusan yang dibuat oleh KLRCA terpakai dalam kalangan 149 negara anggota konvensyen di serata dunia. Oleh itu, penggunaan KLRCA dapat mempromosi Malaysia sebagai pusat timbang tara, dan dalam masa yang sama, sebagai hub kewangan Islam global. ${ }^{97}$ Selain daripada KLRCA, Malaysia juga memiliki pusat-pusat timbang tara lain yang boleh mengendalikan pertikaian dalam kes-kes kewangan Islam seperti Biro Pengantaraan Kewangan (FMB), Pusat Timbang Tara Malaysia (MMC) dan Pusat Timbang Tara Mahkamah Kuala Lumpur (KLCMC). ${ }^{98}$

Walau bagaimanapun, peruntukan yang mengikat pihak mahkamah dan timbang tara menimbulkan keraguan dalam kalangan pengamal undang-undang. Ini kerana, ia telah melanggar prinsip asas keadilan dalam memberi hak kepada semua pihak untuk didengari dalam mahkamah awam. Sebaliknya, peruntukan di atas telah mengehadkan perselisihan dalam permasalahan kewangan Islam kepada satu pihak sahaja iaitu MPS BNM, tanpa membenarkan pihak lain untuk memberikan pandangan dalam permasalahan ini. ${ }^{99}$ Peruntukan ini juga akan menyebabkan pihak mahkamah terpaksa tunduk kepada sebuah badan yang ditubuhkan oleh cabang eksekutif sehingga boleh memberi implikasi

95 Adnan Trakic, 'The Adjudication of Shari'ah issues in Islamic Financial Contracts: Is Malaysian Islamic Finance Litigation A Solution?,' 269.

96 KLRCA kini dikenali sebagai Asian International Arbitration Centre (AIAC) sejak tahun 2018.

97 Arifin Zakaria, 'A Judicial Perspective on Islamic Finance Litigation in Malaysia', $180 \& 181$.

98 Umar Oseni \& Abu Umar Faruq Ahmad Oseni, 'Towards a Global Hub: The Legal Framework for Dispute Resolution in Malaysia's Islamic Finance Industry,' International Journal of Law and Management, vol. 58/5 (2016): 217.

99 Arifin Zakaria, 'A Judicial Perspective on Islamic Finance Litigation in Malaysia', 174. 
yang serius terhadap kebebasan badan kehakiman dan nilai demokrasi itu sendiri. ${ }^{100}$

Sungguh pun begitu, masih terdapat pandangan yang mempertahankan peruntukan ini dengan berhujahkan MPS BNM tidak memainkan peranan sebagai sebuah badan kehakiman. Pertikaian dalam permasalahan kewangan Islam tidak dibawa kepada MPS BNM untuk diadili. Sebaliknya, ia masih kekal di bawah bidang kuasa mahkamah-mahkamah sivil di Malaysia. Cuma, permasalahan yang berkaitan dengan kewangan Islam secara khusus sahaja perlu dirujuk oleh hakim mahkamah sivil kepada keputusan dan pandangan yang dibuat oleh MPS BNM. Ini bertujuan untuk mendapatkan keputusan yang paling tepat kerana ahli-ahli MPS BNM merupakan pihak yang paling berpengalaman dan berautoriti untuk memberi pandangan bagi permasalahan yang berkaitan dengan isu-isu kewangan Islam. ${ }^{101}$

Dari sudut ahli-ahli yang menganggotai MPS BNM pula, mereka terdiri daripada kalangan ahli akademik dan para ulama dalam bidang Syariah yang terkemuka, ahli kewangan dan perbankan yang berkelayakan dan mempunyai pengalaman luas dalam perbankan Islam, kewangan Islam, ekonomi, perundangan Syariah dan bidang-bidang berkaitan yang lain. Kepelbagaian kepakaran dan pengetahuan dalam keahlian MPS BNM ini berpotensi untuk menyumbang kepada pengeluaran hukum syarak dalam bidang kewangan Islam yang lebih mantap dan bersepadu. ${ }^{102}$ Bagi memberi tahap keyakinan yang tinggi terhadap keputusan yang dikeluarkan oleh MPS BNM, ahli-ahli MPS BNM dilantik oleh Yang di-Pertuan Agong dengan nasihat Menteri Kewangan setelah berunding dengan pihak Bank Negara Malaysia. ${ }^{103}$ Ahli-ahli MPS BNM juga tidak dibenarkan untuk menjadi ahli jawatankuasa Syariah di peringkat IKI seperti mana ahli jawatankuasa Syariah IKI tidak dibenarkan

100 Adnan Trakic, 'The Adjudication of Shari'ah issues in Islamic Financial Contracts: Is Malaysian Islamic Finance Litigation A Solution?,' 262.

101 Adnan Trakic, 'The Adjudication of Shari'ah issues in Islamic Financial Contracts: Is Malaysian Islamic Finance Litigation A Solution?,' 270.

102 Nooraslinda Abdul Aris, Othman, R., Mohd Azli, R., Sahri, M., Abdul Razak, D., \& Abdul Rahman, Z., 'Islamic Banking Products: Regulations, Issues and Challenges,' 173; Grassa, R., 'Shariah Supervisory Systems in Islamic Finance Institutions Across the OIC Member Countries: An Investigation of Regulatory Frameworks,' 140 .

103 Arifin Zakaria, 'A Judicial Perspective on Islamic Finance Litigation in Malaysia', 173. Grassa, R., 'Shariah Supervisory Systems in Islamic Finance Institutions Across the OIC Member Countries: An Investigation of Regulatory Frameworks,' 140 . 
untuk menjadi ahli jawatankuasa Syariah di IKI yang lain di bawah industri yang sama (industri perbankan atau industri takaful). Ini bagi menjamin kebebasan dan keadilan dalam membuat sebarang keputusan. ${ }^{104}$

Sekalipun begitu, MPS BNM masih dikritik berhubung ketiadaan garis panduan bertulis atau peraturan bagaimana MPS BNM mengeluarkan sesuatu keputusan. Keputusan yang dikeluarkan oleh MPS BNM pula tidak diberikan sebarang ruang untuk merayu bagi menyatakan rasa tidak puas hati terhadap keputusan yang diberikan. ${ }^{105}$ Sebahagian keputusan yang dibuat oleh MPS BNM pula dikatakan hanya menciplak dan menduplikasikan produk-produk yang terdapat dalam perbankan konvensional. Prinsip-prinsip Syariah atau fiqh pula hanya digunakan bagi untuk mengesahkan dan menjustifikasikan pematuhan Syariah dan menjawab isu-isu Syariah yang terdapat pada produkproduk tersebut. ${ }^{106}$

Selain itu, proses pengeluaran sesuatu keputusan Syariah yang diputuskan oleh MPS BNM masih lagi diklasifikasikan sebagai sulit dan tidak terbuka sebagai bahan rujukan umum. Ini sedikit sebanyak boleh menghalang perkembangan kajian dalam industri perbankan Islam di Malaysia. Ia berbeza dengan perbankan konvensional kerana prosiding mahkamah bagi penafsiran perundangan terhadap sebarang aktiviti perbankan konvensional adalah lebih terbuka dan penghakiman-penghakiman yang penting pula akan dilaporkan di dalam jurnal undang-undang. Justeru itu, dicadangkan bahawa forum terbaik bagi penyelesaian pertikaian dalam isu-isu kewangan Islam adalah di Mahkamah Syariah. Ini merujuk kepada kedudukan para hakim mahkamah Syariah itu sendiri dilantik melalui tauliah yang diberikan oleh Yang diPertuan Agong atau pemerintah-pemerintah di setiap negeri. Mahkamah Syariah juga mempunyai segala kemudahan, pengalaman, undang-undang khusus dan prosedur yang mencukupi untuk menangani sebarang permohonan bagi mendapatkan penghakiman berkenaan hal ehwal agama Islam. Selain itu, perkara yang paling penting adalah prosiding mahkamah Syariah adalah terbuka kepada tatapan dan penilaian umum. Ini pastinya dapat memberi ruang yang lebih besar untuk pelaporan kes-kes tersebut di dalam jurnal undang-

104 Grassa, R., 'Shariah Supervisory System in Islamic Financial Institutions, New Issues and Challenges: A Comparative Analysis between Southeast Asia Models and GCC Models,' 346.

105 Arifin Zakaria, 'A Judicial Perspective on Islamic Finance Litigation in Malaysia', 175.

106 Ruzian Markom, Pitchay, S. A., Zainol, Z. A., Rahim, A. A., \& Merican, R. M. A. R., 'Adjudication of Islamic Banking and Finance Cases in the Civil Courts of Malaysia,' European Journal of Law and Economics, vol. 36/1 (2013): 20. 
undang bagi segala permasalahan yang mempunyai kaitan dengan kontrakkontrak perbankan Islam. ${ }^{107}$

\section{PENGAWASAN SYARIAH DI PERINGKAT GLOBAL}

Kajian-kajian berkenaan pengawasan Syariah di luar negara pula menunjukkan bahawa terdapat tiga bentuk pengawasan Syariah di dalam sistem kewangan Islam. Pertama, terdapat sebahagian negara yang tidak membangunkan rangka kerja pengawal seliaan yang komprehensif bagi pengawasan Syariah. Sekalipun negara-negara terbabit telah memberikan kebenaran untuk menubuhkan beberapa IKI, pihak pengawal seliaan masih mendiamkan diri tentang aspek pengawasan Syariah. Sistem pengawasan Syariah yang ditubuhkan oleh IKI bukan merupakan satu keperluan dari sudut undang-undang. Sebaliknya, ia hanyalah insiatif daripada IKI sendiri akibat terkesan dengan sistem kewangan Islam di peringkat global. Negara-negara yang tidak mempunyai rangka kerja pengawasan Syariah ini adalah seperti Arab Saudi, Turki, Mesir, Tunisia, Lubnan, Thailand dan Kazakhstan. ${ }^{108}$

Bentuk pengawasan kedua pula adalah pengawasan Syariah secara berpusat dan di peringkat institusi. Pengawasan secara berpusat ini dilaksanakan melalui penubuhan badan pengawasan Syariah sebagai pihak berkuasa tertinggi bagi semua IKI dengan tujuan untuk harmonisasi dan penyelarasan fatwa dalam isu kewangan Islam. Sebahagian negara seperti Malaysia, Indonesia, Brunei, Bahrain, Pakistan, Iran, Sudan, Nigeria dan Palestin, pihak bank pusat di negaranegara terbabit telah menubuhkan lembaga pengawasan Syariah di peringkat negara. Negara-negara lain seperti Kuwait, UAE, Qatar, Jordan dan Maghribi pula telah menyerahkan tugas pengawasan Syariah tertinggi kepada badan kerajaan seperti Kementerian Wakaf dan Hal Ehwal Agama atau Kementerian Keadilan dan Hal Ehwal Islam. Badan Pengawasan Syariah berpusat ini mempunyai kuasa untuk menetapkan rangka kerja, polisi dan peraturan bagi industri kewangan Islam. Bagi pengawasan Syariah di peringkat institusi pula,

107 Ahmad Hidayat Buang, 'Islamic Contracts in a Secular Court Setting? Lessons from Malaysia,' Arab Law Quarterly, vol. 21/4 (2007): 325 \& 340.

108 Grassa, R., 'Shariah Supervisory Systems in Islamic Finance Institutions Across the OIC Member Countries: An Investigation of Regulatory Frameworks,' 139 \& 140 . 
ia dikendalikan sama ada oleh pihak IKI itu sendiri, firma perundingan Syariah atau penasihat Syariah tunggal. ${ }^{109}$

Bentuk pengawasan ketiga adalah pengawasan Syariah di peringkat IKI sahaja. Negara-negara seperti Syria, Oman, Yaman, Libya dan Iraq telah mewajibkan pihak IKI untuk menubuhkan badan pengawasan Syariah bebas yang terdiri daripada kalangan para ulama untuk memberi nasihat berkenaan hal-hal Syariah. Badan pengawasan Syariah ini bertanggungjawab untuk memastikan semua produk dan perkhidmatan yang ditawarkan oleh IKI bertepatan dengan kehendak Syariah. Badan ini juga perlu memberi nasihat berkenaan hal-hal Syariah kepada lembaga pengarah IKI dan membantu IKI dalam membentuk produk-produk dan perkhidmatan-perkhidmatan yang terbaru. Selain itu, badan pengawasan Syariah di peringkat IKI perlu memantau dan menyemak secara berkala operasi kewangan IKI serta menyediakan laporan berdasarkan prinsip-prinsip Syariah bagi semua operasi kewangan IKI. ${ }^{110}$

109 Grassa, R., 'Shariah Supervisory Systems in Islamic Finance Institutions Across the OIC Member Countries: An Investigation of Regulatory Frameworks,' 140; Samy Nathan Garas \& Chris Pierce, 'Shariah Supervision of Islamic Financial Institutions,' 390; Hamza, H., 'Sharia Governance in Islamic Banks: Effectiveness and Supervision Model,' 233; Rashīd Șabiḥ, 'al-Lajnah al-Shar'iyyah li alMāliyyah al-Tashārukiyyah,' Majallāt al-Fiqh wa-al-Qānūn, vol. 30 (2015), 63.

110 Grassa, R., 'Shariah Supervisory Systems in Islamic Finance Institutions Across the OIC Member Countries: An Investigation of Regulatory Frameworks,' 139, $147 \& 154$. 
Rajah 7: Bentuk-Bentuk Pengawasan Syariah bagi Institusi-Institusi Kewangan Islam

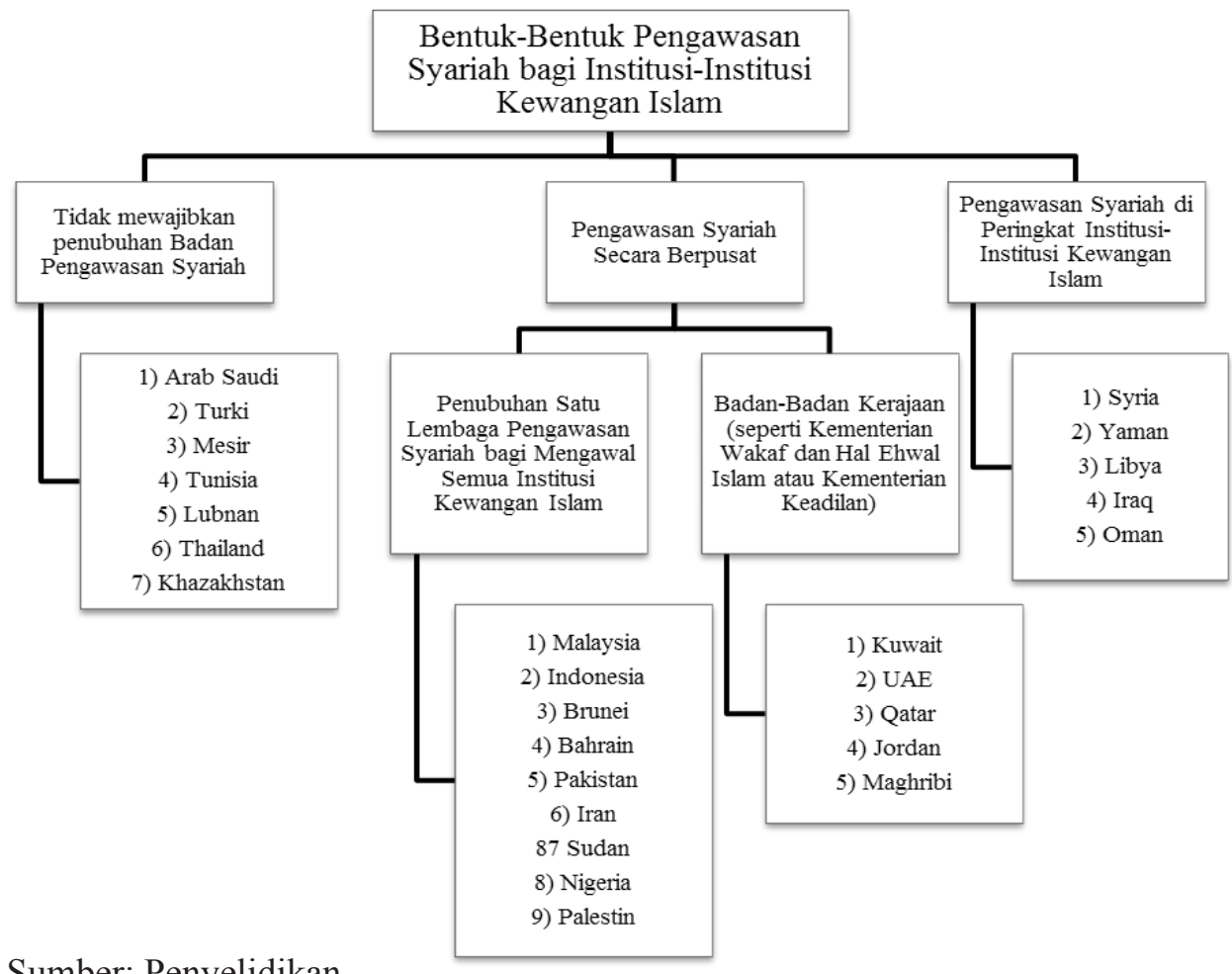

Sumber: Penyelidikan

Daripada ketiga-tiga bentuk pengawasan ini, Hichem Hamza berpandangan model pengawasan Syariah berpusat adalah model terbaik kerana ia mampu mengukuhkan kedudukan dan kebebasan pengawasan Syariah serta membantu dalam perkembangan yang lebih positif bagi industri ini. Ia juga mampu menilai bentuk-bentuk perbezaan di antara IKI-IKI bagi menggalakkan konsistensi dalam pengeluaran fatwa dan penafsiran Syariah bagi satu jangka masa yang panjang. Pandangan ini turut dipersetujui oleh Muhamed Zulkhibri dan Reza Ghazal. ${ }^{111}$ Walau bagaimanapun, badan pengawasan Syariah di peringkat negara ini perlu memainkan peranan yang lebih penting dalam mengawal dan memastikan amalan tadbir urus perbankan Islam dilaksanakan sepenuhnya. Ini kerana, Sekalipun negara-negara yang mengamalkan model

111 Hamza, H., 'Sharia Governance in Islamic Banks: Effectiveness and Supervision Model,' 236; Muhamed Zulkhibri Abdul Majid \& Reza Ghazal, 'Comparative Analysis of Islamic Banking Supervision and Regulation Development,' 149. 
ini telah menubuhkan badan pengawasan Syariah di peringkat negara, masih terdapat perbezaan dari sudut peranan dan tanggungjawab di antara satu negara dengan yang lain. Sebahagian badan pengawasan Syariah peringkat negara ini mempunyai kemampuan untuk membentuk rangka kerja tadbir urus Syariah dan meletakkan polisi dan peraturan untuk industri kewangan Islam. Di negara yang lain pula, badan pengawasan Syariah peringkat negara hanya memainkan peranan ketika berlaku perselisihan pendapat dalam kalangan ahli-ahli badan pengawasan Syariah di peringkat IKI. Selain daripada keadaan tersebut, ia tidak mempunyai sebarang kuasa terhadap badan pengawasan Syariah di peringkat IKI dan tidak boleh juga mengeluarkan sebarang arahan terus kepada IKI. Ketiadaan atau kelemahan pengawasan dan pengawalan di peringkat negara akan membenarkan pembentukan produk-produk yang meragukan atau produk berasaskan riba sekalipun ia dilabelkan sebagai produk yang patuh Syariah. Ia juga akan menyebabkan berlaku kekeliruan dan pengedaran fatwafatwa pelik yang akan membahayakan kredibiliti produk kewangan Islam pada pandangan masyarakat muslim dan seterusnya membahayakan pembangunan dan kestabilan sektor kewangan Islam. ${ }^{12}$

\section{KAEDAH PENGELUARAN HUKUM DAN FATWA-FATWA DALAM BIDANG KEWANGAN ISLAM}

Berhubung kaedah pengeluaran hukum bagi permasalahan dalam kewangan Islam, tidak diketahui sehingga kini mana-mana negara yang meletakkan peraturan atau undang-undang khusus yang menerangkan tatacara penggunaan perundangan Syariah ketika membuat keputusan berkenaan pematuhan Syariah sesuatu produk atau perkhidmatan. ${ }^{113}$ Perkara ini turut dikenal pasti berlaku di Malaysia seperti mana kritikan yang dibuat oleh Arifin Zakaria sebelum ini. ${ }^{114}$ Walau bagaimanapun, bagi negara Indonesia, terdapat metodologi fatwa yang digunakan oleh Dewan Syariah Nasional Majelis Ulama Indonesia (DSNMUI) sebagai badan pengawasan Syariah peringkat Nasional yang mengawal selia kegiatan perbankan Syariah di Indonesia. DSN-MUI telah menggunakan kaedah Jawatankuasa Fatwa Majelis Ulama Indonesia sebagaimana yang

112 Grassa, R., 'Shariah Supervisory Systems in Islamic Finance Institutions Across the OIC Member Countries: An Investigation of Regulatory Frameworks,' 155; Grassa, R., 'Shariah Supervisory System in Islamic Financial Institutions, New Issues and Challenges: A Comparative Analysis between Southeast Asia Models and GCC Models,' 342.

113 Muhamed Zulkhibri Abdul Majid \& Reza Ghazal, 'Comparative Analysis of Islamic Banking Supervision and Regulation Development,’ 149.

114 Arifin Zakaria, 'A Judicial Perspective on Islamic Finance Litigation in Malaysia', 175. 
ditetapkan dalam Pedoman Penetapan Fatwa Majelis Ulama Indonesia. Berdasarkan Pedoman ini, setiap fatwa termasuklah dalam bidang ekonomi perlu berdasarkan sumber Syariah yang empat iaitu al-Quran, Sunnah, ijmā dan qiyās. Namun begitu, pendapat para imam mazhab perlu dilihat terlebih dahulu secara saksama terutamanya dalam memberi penilaian terhadap dalildalil yang menjadi sandaran pendapat imam mazhab tersebut. Sekiranya sesuatu hukum tidak terdapat dalam mana-mana mazhab, penetapan fatwa hendaklah berdasarkan ijtihad jamā' $\bar{\imath}$ melalui kaedah bayānī, ta 'līlì, istiṣlāḥ̄ dan sadd al-dharā' $i$ ' ${ }^{115}$

Kajian-kajian yang berbentuk analisis terhadap fatwa-fatwa yang dikeluarkan oleh badan pengawasan Syariah pula adalah seperti kajian Noor Suhaida Kasri yang menganalisis resolusi Syariah yang dikeluarkan Majlis Penasihat Syariah Suruhanjaya Sekuriti Malaysia. Resolusi tersebut adalah keputusan dikeluarkan Majlis Penasihat Syariah Suruhanjaya Sekuriti Malaysia yang membenarkan kontrak niaga hadapan minyak sawit mentah. Walau bagaimanapun, Noor Suhaida telah memberi pandangan yang bertentangan dengan keputusan yang dibuat oleh Majlis Penasihat Syariah Suruhanjaya Sekuriti Malaysia. Beliau berpendapat kontrak niaga hadapan minyak sawit mentah tidak sunyi daripada elemen ketidakpastian (gharar) dan perjudian (maysīr). Oleh itu, kontrak seperti ini sepatutnya tidak dibenarkan seperti mana fatwa yang dikeluarkan oleh Akademi Fiqh Islam OIC dan The Accounting and Auditing Organisation for Islamic Financial Institutions (AAOIFI). ${ }^{116}$

Ahcene Lahsasna pula mengemukakan beberapa resolusi yang dikeluarkan oleh MPS BNM dan Majlis Penasihat Syariah Suruhanjaya Sekuriti Malaysia untuk dianalisis bagi memahami metodologi sesuatu fatwa, bentuk penghujahan dan perbincangan sehingga menghasilkan satu resolusi yang mesti dipatuhi oleh pihak-pihak tertentu. Beliau telah mengemukakan resolusi MPS BNM berkenaan ta'wi d dan gharamah dalam pembiayaan kewangan Islam dan resolusi berkenaan kaedah caj lewat bayar ke atas hutang penghakiman. Bagi Majlis Penasihat Syariah Suruhanjaya Sekuriti Malaysia pula, penulis telah menganalisis resolusi berkenaan kriteria Syariah bagi sekuriti tersenarai, syarikat bercampur dan imej sebagai kriteria sekuriti tersenarai. Penulis telah memberikan penjelasan dan huraian lanjut berkenaan resolusi tersebut terlebih

115 Ahmad Hidayat Buang \& M. Cholis Nafis, 'Peranan MUI dan Metodologi Istinbat Fatwa dalam Undang-Undang Perbankan Syariah di Indonesia,' Jurnal Pengurusan, vol. 35/ 10 (2012): 58 \& 59.

116 Noor Suhaida Kasri, 'A Critical Analysis of the Resolution of the Shariah Advisory Council of Securities Commission Malaysia: A Case Study of the Crude Palm,' ISRA International Journal of Islamic Finance, vol. 5/2 (2013): 141 \& 145. 
dahulu. Kemudian, penulis telah mengemukakan hujah bagi setiap resolusi tersebut daripada sumber-sumber hukum yang utama, kaedah-kaedah fiqh, pandangan ulama mazhab dan pandangan ulama kontemporari. ${ }^{117}$

\section{KESIMPULAN}

Berdasarkan kepada kajian-kajian di atas, penyelidik berpandangan bahawa kajian berkenaan konsep talfiq adalah wajar untuk diteruskan bagi menyempurnakan lagi kefahaman berkenaan konsep talfiq ini. Dari sudut takrif talfiq, para pengkaji sering merujuk kepada takrif yang dikeluarkan oleh al-Bani. Manakala takrif yang dikemukakan oleh Abdullah@Alwi Hassan, Gerber dan al-Muhairi pula adalah terlalu ringkas sehingga boleh menyebabkan berlaku kekeliruan di antara konsep talfiq dengan konsep-konsep yang lain. Takrif al-Zuhaylī pula, sekalipun agak lengkap, akan tetapi takrif tersebut terlalu panjang sehingga tidak sesuai digunakan sebagai takrif bagi sesuatu konsep. Justeru itu, penyelidik berpandangan bahawa kajian boleh terus dilakukan bagi mengeluarkan satu takrif yang lengkap dan menepati maksud sebenar daripada konsep talfiq.

Berhubung hukum talfiq pula, penyelidik mendapati bahawa hujah bagi kedua-dua golongan yang menyokong dan menentang konsep talfiq sangat banyak dan berada dalam penulisan-penulisan yang berbeza. Kajian secara khusus berkenaan konsep talfiq masih tidak menghimpunkan kebanyakan hujah-hujah tersebut untuk dianalisis dan diperbincangkan secara lebih teliti. Justeru itu, kajian lanjutan berkenaan hujah-hujah tersebut perlu dilakukan bagi melengkapkan lagi hujah-hujah berkenaan konsep talfiq agar satu kesimpulan yang tepat dapat dilakukan berkenaan hukum penggunaan konsep talfiq pada masa kini.

Seterusnya, penyelidik juga telah menjelaskan kajian-kajian yang mempunyai kaitan dengan konsep pengawasan Syariah di institusi-institusi kewangan Islam sama ada yang dilaksanakan di Malaysia mahu pun di luar negara. Justeru itu, kajian lanjutan yang dicadangkan adalah penyelidikan yang memberi tumpuan kepada kaedah penyelesaian hukum yang digunakan oleh badan-badan pengawasan Syariah di institusi-institusi kewangan Islam di Malaysia. Ini disebabkan ketiadaan garis panduan bertulis berkenaan kaedah pengeluaran hukum tersebut yang digunakan oleh badan-badan pengawasan Syariah di institusi-institusi kewangan Islam di Malaysia. Selain itu, kajian lanjutan juga boleh dilakukan bagi menganalisis penggunaan konsep talfiq

117 Ahcene Lahsasna, Introduction to Fatwa, Shariah Supervision \& Governance in Islamic Finance (Kuala Lumpur: CERT Publications Sdn. Bhd., 2010), 263-307. 
sebagai salah satu kaedah penyelesaian hukum yang digunakan dalam pengeluaran fatwa-fatwa atau resolusi-resolusi di institusi-institusi kewangan Islam di Malaysia

\section{RUJUKAN}

Al-'Ațibī, G. bin M., 'al-Talfīq bayn al-Madhāhib al-Fiqhiyyah wa 'Alaqātuhu bi Taysīr al-Fatwā,' (Garis Panduan Fatwa anjuran al-Majma' al-Fiqh al-Islāmī, Arab Saudi, Makkah, 17-20 Januari 2009).

Abdulhamid Abdullah al-Hargan, 'Saudi Arabia and the International Covenant on Civil and Political Rights 1966: A Stalemate Situation,' The International Journal of Human Rights, vol. 9/4 (2005): 491-505.

Abdullah@Alwi Hassan, 'Ijtihad dan Peranannya dalam Pengharmonian Pengamalan Undang-Undang Syariah di Dunia Islam Masa Kini,' Jurnal Syariah, vol. 15/2 (2007): 1-24.

Adnan Trakic, 'The Adjudication of Shari'ah issues in Islamic Financial Contracts: Is Malaysian Islamic Finance Litigation A Solution?,' Humanomics, vol. 29/4 (2013): 260-275.

Ahcene Lahsasna, Introduction to Fatwa, Shariah Supervision \& Governance in Islamic Finance (Kuala Lumpur: CERT Publications Sdn. Bhd., 2010).

Ahmad Hidayat Buang \& M. Cholis Nafis, 'Peranan MUI dan Metodologi Istinbat Fatwa dalam Undang-Undang Perbankan Syariah di Indonesia,' Jurnal Pengurusan, vol. 35/ 10 (2012): 57-69.

Ahmad Hidayat Buang, 'Islamic Contracts in a Secular Court Setting? Lessons from Malaysia,' Arab Law Quarterly, vol. 21/4 (2007): 317-340.

Anisah Ab. Ghani, Abdul Karim Ali, Noor Naemah Abd. Rahman, Raihanah Azahari, Saadan Man, Luqman $\mathrm{Hj}$ Abdullah \& Shahidra Abdul Khalil, 'Penerimaan Masyarakat Islam di Malaysia Terhadap Amalan Percampuran Mazhab di Malaysia,' Jurnal Fiqh, vol. 4 (2007): 197-222.

Arifin Zakaria, 'A Judicial Perspective on Islamic Finance Litigation in Malaysia,' IIUM Law Journal, vol. 21/2 (2013): 143-182.

Āyah 'Abd al-Salām, 'al-Talfīq wa Tatabbu' al-Rukhaṣ wa Taṭīiātuhu fī al'Ibādat wa al-Ahwāl al-Shakhsiyyah,' (Disertasi Sarjana, Jami'ah alKhalīl, Hebron, Palestin, 2006).

Badr al-Dīn Muḥammad bin Bahadur al-Zarkashī, al-Bahr al-Muhiț, vol. 6 (Hurghada: Dār al-Șafwah, 1992). 
Al-Banī, M. S., 'Umdah al-Taḥqīq fì al-Taqlid wa al-Talfìq (Dimashq: Dār al-Qadirī, 1997).

Butti Sultan Butti Ali al-Muhairi, 'Conclusion to the Series of Articles on the UAE Penal Law,' Arab Law Quarterly, vol. 12/4 (1997): 384-399.

Daromir Rudnyckyj, 'From Wall Street to Halal Street: Malaysia and the Globalization of Islamic Finance,' The Journal of Asian Studies, vol. 72/4 (2013): 831-848.

Fareeha Khan, 'Traditionalist Approaches to Shariah Reform: Mawlana Ashraf Ali Thanawi Fatwa on Women Right to Divorce,' (Ph.D Thesis, The University of Michigan, USA, 2008).

Fazlur Rahman, 'Islamic Method Modernism: Its Scope, Method and Alternative,' International Journal of Middle East Studies, vol. 1/4 (1970): 317-333.

Grassa, R., 'Shariah Supervisory System in Islamic Financial Institutions, New Issues and Challenges: A Comparative Analysis between Southeast Asia Models and GCC Models,' Humanomics, vol. 29/4 (2013): 333-348.

Grassa, R., 'Shariah Supervisory Systems in Islamic Finance Institutions Across the OIC Member Countries: An Investigation of Regulatory Frameworks,' Journal of Financial Regulation and Compliance, vol. 23/2 (2015): 135-160.

Haim Gerber, 'Rigidity versus Openness in Late Classical Islamic Law: The Case of the Seventeenth-Century Palestinian Muftī Khayr al-Dīn alRamlī', Islamic Law and Society, vol. 5/2 (1998): 165-195.

Hamza, H., 'Sharia Governance in Islamic Banks: Effectiveness and Supervision Model,' International Journal of Islamic and Middle Eastern Finance and Management, vol. 6/3 (2013): 226-237.

Hayyam Muḥammad 'Abd al-Qādir al-Zaydaniyyin, 'al-Riqābah al-Shar'iyyah 'ala al-Mașārif al-Islāmiyyah bayna al-Ta'sil wa al-Taṭbīq,' Dirāsāt 'Ulüm al-Sharì' 'ah wa al-Qānūn, vol. 40/1 (2013): 89-110.

Ibrahim, Y. S., 'The Spirit of Islamic Law and Modern Religious Reform: Maqasid al-Shari'a in Muhammad 'Abduh and Rashid Rida's Legal Thought' (Ph.D Thesis, Princeton University, New Jersey, United States of America, 2004).

Inarah Ahmad Farid \& Saadan Man, 'Keterbukaan Bermazhab dalam Realiti di Malaysia: Keperluan atau Kecelaruan?,' Jurnal Syariah, vol. 20/3 (2012): 289-308. 
Indira Falk Gesink, 'Islamic Reformation: A History of Madrasa Reform and Legal Change in Egypt,' Comparative Education Review, vol. 50/3 (2006): 325-345.

Al-Khalaylah, B. M., 'Mada Taț̣īq al-Mu'assasah al-Māliyyah al-Islāmiyyah al-Urdūniyyah li al-Mi'yar al-Muḥāsib̄̄ al-Islāmī al-Murābaḥah wa al-Murābaḥah al-Amīr bi al-Shirā',' (Master Dissertation, al-Bayt University, 2008).

Khālid bin Musa'id al-Ruwayti‘, al-Tamadhhub, vol. 2 (Riyāḍ: Dār alTadmūriyyah, 2013).

Khan, G.G., 'Application of Talfiq in Modern Islamic Commercial Contracts,' Policy Perspectives, vol. 10/2 (2013): 141-166.

Krawietz, B., 'Cut and Paste in Legal Rules: Designing Islamic Norms with Talfiq,' Die Welt Des Islams, vol. 42/1 (2002): 3-40.

Layish, A., 'The Transformation of the Sharī'a from Jurists' Law to Statutory Law in the Contemporary Muslim World,' Die Welt Des Islams, vol. 44/1 (2004): 85-113.

Lutz Wiederhold, 'Legal Doctrines in Conflict the Relevance of Madhhab Boundaries to Legal Reasoning in the Light of an Unpublished Treatise on Taqlīd and Ijtihād,' Islamic Law and Society, vol. 3/2 (1996): 234304.

Maszlee Malik, 'Hukum Talfiq dalam Muamalat: Kajian terhadap Bay' alMurābaḩah li al-Amir bi al-Shira' di Bank Islam Malaysia Berhad (BIMB),' (Disertasi Sarjana, Jabatan Fiqh dan Usul, Akademi Pengajian Islam, Universiti Malaya, Kuala Lumpur, 2004).

Maszlee Malik, Talfiq: Beramal dengan Pelbagai Mazhab (Shah Alam: Karya Bestari Sdn. Bhd., 2005).

Mohammad Azam Hussain, Rusni Hassan \& Aznan Hasan, 'Analysis on the Development of Legislations Governing Shariah Advisory Council of Bank Negara Malaysia,' Jurnal Syariah, vol. 23/2 (2015): 325-342.

Mohammad Hashim Kamali, 'Shari' ah and Civil Law: Towards A Methodology of Harmonization,' Islamic Law and Society, vol. 14/3 (2007): 391-420.

Muhamed Zulkhibri Abdul Majid \& Reza Ghazal, 'Comparative Analysis of Islamic Banking Supervision and Regulation Development,' Money and Economy, vol. 6/3 (2012): 113-162.

Muḥammad Aḥmad Mustarihi, 'Ta'amul al-Jam'iyyat al-Ta'awūniyyah alIstithmāriyyah ma'a al-'Umala al-Dirāsah Fiqhiyyah Muqāranah,' (Ph.D Thesis, The World Islamic Sciences and Education University, Jordan, 2012). 
Muhammad Faḍīl Muṣțafā, 'al-Talfīq bayna al-Madhāhib wa Athāruhu fī alFiqh al-Islāmī,' (Ph.D Thesis, International Islamic University Malaysia, 1998).

Nașīr 'Abd Allāh al-Mayman, 'al-Talfīq fi al-Ijtihād wa al-Taqlid,' al-Nawāzil al-Tashri 'iyyah (Al-Dammam: Dār Ibn al-Jawzī, 2008), 5-30.

Nicholas H.D. Foster, 'Islamic Perspectives on the Law of Business Organisations II: The Sharia and Western-style Business Organisations,' European Business Organization Law Review, vol. 11/2 (2010): 273307.

Noor Suhaida Kasri, 'A Critical Analysis of the Resolution of the Shariah Advisory Council of Securities Commission Malaysia: A Case Study of the Crude Palm,' ISRA International Journal of Islamic Finance, vol. 5/2 (2013): 141-146.

Nooraslinda Abdul Aris, Othman, R., Mohd Azli, R., Sahri, M., Abdul Razak, D., \& Abdul Rahman, Z., 'Islamic Banking Products: Regulations, Issues and Challenges,' Journal of Applied Business Research, vol. 29/4 (2013): 1145-1156.

Nūr Shahīrah Muhammad Nașīr, al-Naẓr fī Ma'alat al-Af'āl fī al-Ta'amul ma ‘a al-Shabakah al-'Ankabūtiyyah: Dirāsah Maqāṣidiyyah Taṭbīqiyyah,' (Master Dissertation, al-Bayt University, 2013).

R. Michael Feener, 'Indonesian Movements for the Creation of a National Madhhab,' Islamic Law and Society, vol. 9/1 (2002): 83-115.

Rashīd Șabiḥ, 'al-Lajnah al-Shar'iyyah li al-Māliyyah al-Tashārukiyyah,' Majallāt al-Fiqh wa-al-Qānūn, vol. 30 (2015), 62-70.

Ruzian Markom, Pitchay, S. A., Zainol, Z. A., Rahim, A. A., \& Merican, R. M. A. R., 'Adjudication of Islamic Banking and Finance Cases in the Civil Courts of Malaysia,' European Journal of Law and Economics, vol. 36/1 (2013) 1-34.

Ruzman Md. Noor, 'Kedudukan Bayyinah, Syahādah dan Qarīnah dalam Penggubalan Undang-Undang Islam di Malaysia,' Jurnal Syariah, vol. 16/2 (2008): 345-366.

Sa'ad al-'Anz̄̄, 'al-Talfīq fī al-Fatawā,' Majallah al-Sharī'ah wa al-Dirāsah al-Islāmiyyah, vol. 38 (1999), 269-308.

Al-Sa'idī, A. bin M., 'al-Talfīq wa Ḥukmuhu fī al-Fiqh al-Islāmī,' (Garis Panduan Fatwa anjuran al-Majmā' al-Fiqh al-Islāmī, Arab Saudi, Makkah, 17-20 Januari 2009). 
Șafiyyah 'Alī al-Shar', 'Tatabbu' al-Rukhaș, Dirāsah Naqdiyyah li Ra'y al-Imām al-Shāṭib̄i,' Majallah Jami 'ah al-Shariqah li al- 'Ulūm alShar 'iyyah wa al-Qanūniyyah, vol. 11/1 (2014), 166-204.

Șafwan Muḥammad Rị̣ā' 'Alī 'Udaybat, 'al-Tarakhkhus fì Masā'il al-Ikhtilāf fī al-Fiqh al-Islāmī: Dirāsah Ta’siliyyah Taṭbīqiyyah-Masā'il Mu'āmalāt fī Qarārāt Majma‘ al-Fiqh al-Islāmī fì Jaddah Anmudhajan,' (Ph.D Thesis, The World Islamic Sciences and Education University, Jordan, 2012).

Saminaz Zaman, 'Amrikan Shari'a: The Reconstruction of Islamic Family Law in the United States,' South Asia Research, vol. 28/2 (2008): 185202.

Samuela Pagani, 'The Meaning of the Ikhtilaf al-Madhahib in Abd al-Wahhab al-Sha'rani's al-Mizan al-Kubra,' Islamic Law and Society, vol. 11/2 (2004): 177-212.

Samy Nathan Garas \& Chris Pierce, 'Shariah Supervision of Islamic Financial Institutions,' Journal of Financial Regulation and Compliance, vol. 18/4 (2010): 386-407.

Sulayman Yūsuf al-Shayhan, 'al-Fatwā fī al-Urdun Tarīkhan wa Fiqhan wa Manhajan,' (Ph.D Thesis, University of Jordan, 2008).

Tawfīq Aḥmad al-Ghalbazūrī, 'al-Fatwā al-Mu'āsirah bayna al-Indibāt wa alIdtirāb: al-Fatawā al-Shazzah Namūzajan,' Majallah al-Mudawwanah, vol. 3 (2014), 221-262.

Umar Oseni \& Abu Umar Faruq Ahmad Oseni, 'Towards a Global Hub: The Legal Framework for Dispute Resolution in Malaysia's Islamic Finance Industry,' International Journal of Law and Management, vol. 58/5 (2016): 217-238.

Wael B. Hallaq, 'Juristic Authority vs State Power: The Legal Crises of Modern Islam,' Journal of Law and Religion, vol. 19/2 (2004): 243-258.

Wahbah al-Zuhaylī, al-Rukhaș al-Shar 'iyyah (Bayrūt: Dār al-Khayr, 1993).

Yāsīn Karamatullah Makhdum, 'Muștalaḥ (al-Qawl al-Gharīb) fī al-Fiqh: Mafhūmuhu wa Ḍābițuhu wa Āthāruhu fì Naql al-Khilāf al-Fiqhi wa al-Futya Dirāsah Istiqra'iyyah Muqāranah,' Majallat al-Jam 'īyah alFiqhīyah al-Sa 'ūdìyah, vol. 19 (2014), 126-341. 
Jurnal Syariah, Jil. 27, Bil. 1 (2019) 77-112 